Portland State University

PDXScholar

$5-12-1982$

\title{
The Descriptive Function of Language: Changes with Age and Pressure to Inform
}

Eve Susan Liebman

Portland State University

Follow this and additional works at: https://pdxscholar.library.pdx.edu/open_access_etds

Part of the Gerontology Commons, and the Speech Pathology and Audiology Commons Let us know how access to this document benefits you.

\section{Recommended Citation}

Liebman, Eve Susan, "The Descriptive Function of Language: Changes with Age and Pressure to Inform" (1982). Dissertations and Theses. Paper 3217.

https://doi.org/10.15760/etd.3208

This Thesis is brought to you for free and open access. It has been accepted for inclusion in Dissertations and Theses by an authorized administrator of PDXScholar. Please contact us if we can make this document more accessible: pdxscholar@pdx.edu. 
AN ABSTRACT OF THE THESIS OF EVe Susan Liebman for the Master of Science in Speech Communication, with an emphasis in Speech Pathology/Audiology, presented May 12, 1982.

Title: The Descriptive Function of Language: Changes with Age and Pressure to Inform.

APPROVED BY MEMBERS OF THE THESIS COMMITTEE:

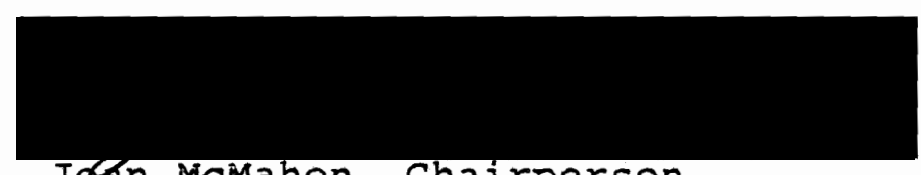

Joan McMahon, Chairperson
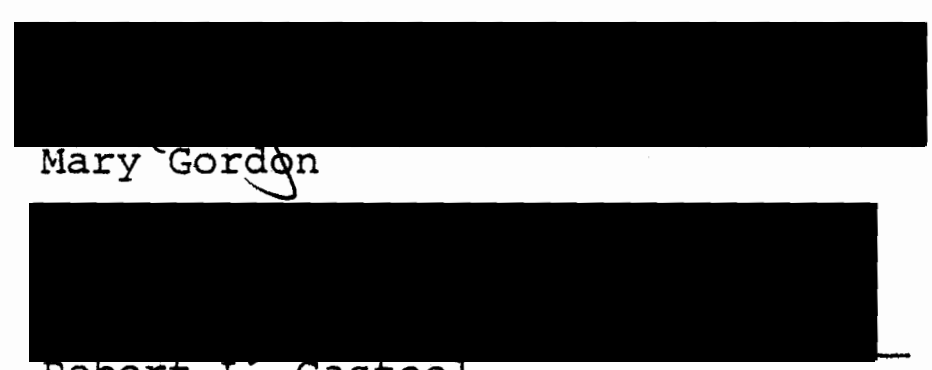

Robert L. Castee1

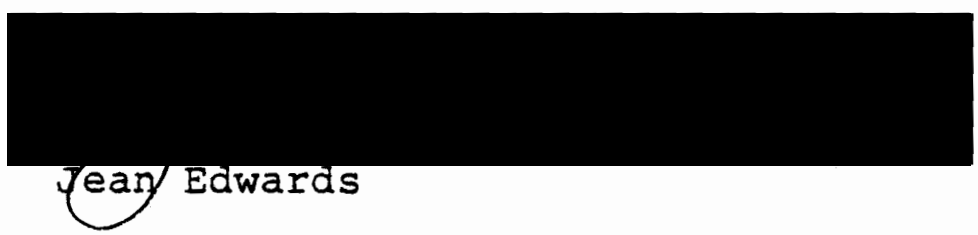

Currently language is viewed as a multi-dimensional construct, consisting of three interrelated components; content, form and function (BIoom and Lahey, 1978). In recent publications, language function has been referred to as 
pragmatics (Prutting, 1979). The essence of pragmatic theory is that language is used functionally in social contexts, to accomplish specific types of communication (Wood, 1981). One such communicative function is referred to as the informative function, which occurs when a speaker provides ideas and information to others, as in describing, naming and giving examples (Wood, 1981). It is not clear, however, when children become competent in making specific, clear statements when describing a referent or event. No study, found by this writer, has provided a detailed analysis of the changes that may occur in baseline descriptive strategies when children are placed under pressure to provide more information. Such data could provide additional insight into children's descriptive abilities at different stages of development.

The questions posed in this investigation were:

Does referential communication vary under pressure among four, six and eight year old children? and (2) How do four, six and eight year old children's descriptions vary when they are pressured to provide more information?

Subjects were eighteen children, six from each age level, selected from an elementary school and a preschool in the metropolitan Portland area. A total of ten picture sets, each containing four pictures, was used in the investigation. Each subject was allowed two trials to describe one of the four pictures to a listener. The listener did not select the picture described until the second trial for all 
subjects. Each subject's description for trial one and trial two was scored as one of the following types of communication: incomplete, contrastive or repetitive.

The results showed significant differences, with added pressure, in trial two between four and eight and six and eight year old children's contrastive and incomplete descriptions, but nonsignificant differences between four and six year old children's contrastive and incomplete descriptions. In trial one, significant differences were found between all age groups contrastive and incomplete descriptions. Repetitive communication occurred only in the four year old age group.

Results also revealed that, in trial one, contrastive descriptions increased with age while incomplete descriptions decreased with age. In trial two, however, children of the four and six year old age group had an identical number of both contrastive and incomplete descriptions, while the eight year old children, in comparison, emitted more contrastive descriptions than the four and six year old children. In addition, the results indicated that only the four year old children increased their contrastive descriptions when more pressure was added. It was speculated that these findings reflect, for the younger children, egocentric behavior and a lack of revision strategies. For the older children, it was surmised that added pressure resulted in high anxiety levels and strategy changes.

Although sex was not included in the original 
questions, it was examined post hoc and appeared to have an effect in this investigation. In the six and eight year old age group, males showed a higher number of contrastive descriptions than females in trial one and trial two. The four year old age group consisted of six females, thus a sex comparison could not be made. 
THE DESCRIPTIVE FUNCTION OF LANGUAGE:

CHANGES WITH AGE AND PRESSURE TO INFORM

by

EVE SUSAN IIEBMAN

A thesis submitted in partial fulfillment of the requirements for the degree of

MASTER OF SCIENCE IN SPEECH COMMUNICATION:

with an emphasis in

SPCECH PATHOLOGY/AUDIOLOGY

Portland State University

1982 
TO THE OFFICE OF GRADUATE STUDIES AND RESEARCH:

The members of the Committee approve the thesis of

Eve Susan Iiebman presented May 12, 1982.

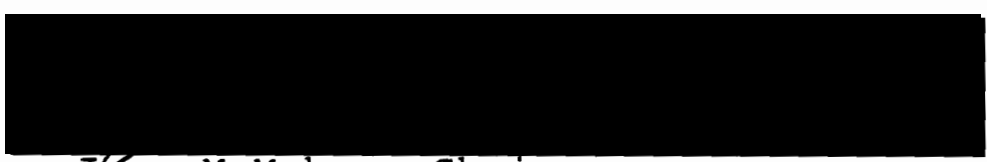

J6an McMahon, Chairperson

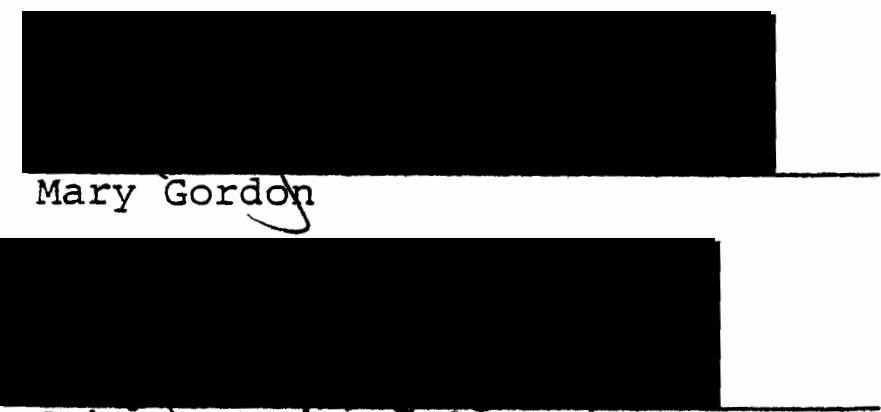

Robert I. Ćasteel

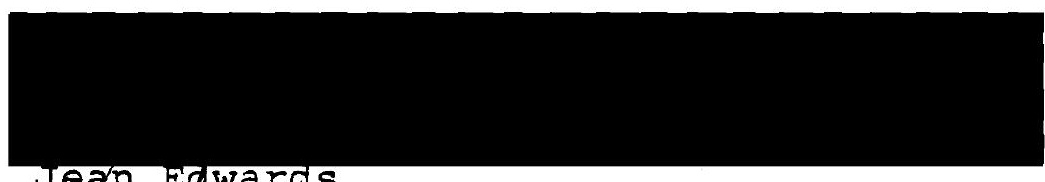

Jean Eqwards

APPROVED :

Theodore Grove, Chair, Department

of Speech Communication

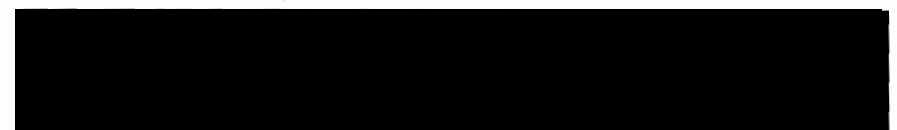

Stanley E. Rauch, Dean, Graduate

Studies and Research 


\section{ACKNOWLEDGE:MENTS}

Special thanks and appreciation is extended to my committee chairperson and graduate advisor, Joan McMahon, for her strong support and assistance. Special thanks also is extended to the members of my committee: Mary Gordon, Dr. Robert Casteel and Jean Edwards for their input and support. I would also like to thank Ted Grove for his assistance with the statistics and special thanks and appreciation goes to Nancy Bowen, who unselfishly gave of her time to help with the statistical analysis.

Many thanks must go to Mr. Jack Barger and sue and Casey Corliss for their generous time, effort, and support in running this study.

To my judges, Molly secrest and Gail Cunningham; my sounding board, Renee Chambers; and my close friends, K.B. and Marilyn Caum, special thanks for your constant support and encouragement.

Much love and appreciation goes to my mother, father and grandparents for always being supportive throughout my educational career.

Finally I wish to express ny deepest love and appreciation to my husband, Ben, and my sister, Jackie, for their tremendous support, encouragement, patience and belief in me during my graduate study. Without their love and support 
this research would not have been possible. 
TABLE OF CONTENTS

Page

ACKNOWLEDGEMENTS

iii

LIST OF TABLES

vi

IIST OF FIGURES

vii

CHAPTER

I INTRODUCTION

Statement of Purpose $\ldots \ldots \ldots \ldots \ldots \ldots \ldots$. 4

Definitions $\quad \ldots \ldots \ldots \ldots \ldots \ldots \ldots \ldots \ldots \ldots \ldots \ldots \ldots$

II REVIEW OF THE LITERATURE 7

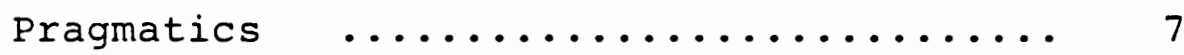

Aspects of Communicative Competence ... 9

Referential Communication $\ldots \ldots \ldots \ldots \ldots 16$

III METHODS AND PROCEDURES 24

Selection of Subjects $\ldots \ldots \ldots \ldots \ldots \ldots . .24$

Screening Instrumentation $\ldots \ldots \ldots \ldots \ldots 24$

Experimental Stimuli and Instrumentation 24

Screening procedure .............. 25

Description of Subjects $\ldots \ldots \ldots \ldots \ldots \ldots 26$

Experimental Procedure $\ldots \ldots \ldots \ldots \ldots \ldots 26$

Data Scoring and Analysis $\ldots \ldots \ldots \ldots \ldots 28$

IV RESULTS AND DISCUSSION 30

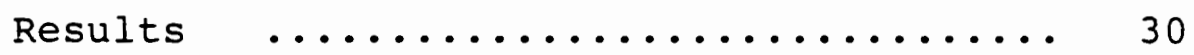

Discussion $\ldots \ldots \ldots \ldots \ldots \ldots \ldots \ldots \ldots \ldots, 42$

$\begin{array}{lll}\mathrm{V} & \text { SUMMARY AND IMPICATIONS } & 49\end{array}$

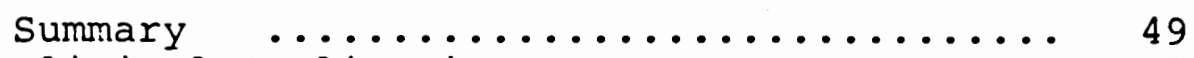

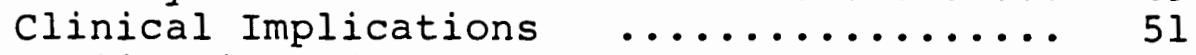

Implications for Further Research ..... 52

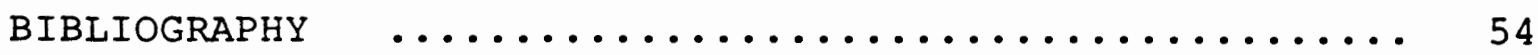

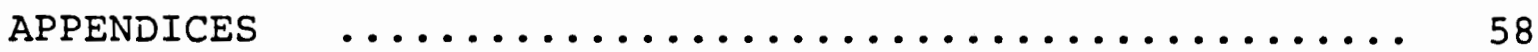




\section{LIST OF TABLES}

TABLE

Page

I Analysis of Variance for Contrastive

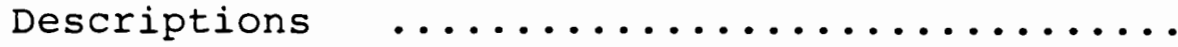

I Analysis of Variance for Incomplete Descriptions

II Raw Data on Contrastive Descriptions with Cell Totals

IV Raw Data on Incomplete Descriptions with Cell Totals

$V$ Scheffé Post Hoc Test for Age Group Comparison of Contrastive Descriptions ..... 35

VI Scheffé Post Hoc Test for Age Group Comparison of Incomplete Descriptions

VII A Comparison of Age Group Mean Scores and Standard Deviations for Trial 1 and Trial 2 . 36

VIII $t$ Values for Differences Between Pairs of $\bar{A} g e$ Group Means for Contrastive Descriptions

IX Percentage of Contrastive and Incomplete Description Differences Between Trials 


\section{LIST OF FIGURES}

FIGURE

Page

1. Illustration of the Relationship Between Ages for Contrastive, Incomplete and Repetitive Descriptions within Trials

2. Illustration of Sex Differences and PPVT-R Scores in Trial 1 and Trial 2 Contrastive Descriptions 
CHAPTER I

INTRODUCTION

Within the past decade, there has been a great surge of research interest in the area of language. Currently, language is viewed as a multi-dimensional construct, consisting of three major interrelated components; content, form, and function (Bloom and Lahey, 1978; Prutting, 1979; Daniloff, Shuckers and Feth, 1980). The first component, language content, refers to an individual's observations, integrations, and generalizations of environmental events (Daniloff et al., 1980). Language content represents those things individuals talk about or understand in messages from others (Bloom and Lahey, 1978). The second component, language structure, refers to the organization of utterances. According to Daniloff et al. (1980), "language structure is the way in which sounds, syllables, words, phrases, and sentences are ordered and structured so that they can represent the content of speech." The third component, language function, refers to the reasons why individuals speak and the way in which speakers use language (Bloom and Lahey, 1978; Daniloff et al., 1980; Wood, 1981).

Until recently, the ability to use language in interpersonal communication was rarely the focus of research on 
language development. Rather, the emphases were placed on the development of language content and structure (Ervin-Tripp, 1956; Dale, 1976). Consequently, there is an abundance of knowledge about the developmental course of phonology, syntax and semantic systems, and a relatively small amount of information on the use of language for commurication.

In recent publications, the use of language has been referred to as pragmatics (Bates, 1976; Prutting, 1979; Wood, 1981). Pragmatic theory focuses on communication in the social interactions of humans (Bates, 1976; Miller, 1978). Pragmatics is defined as a set of rules governing the use of language in social contexts (Bates, 1976). According to Wood (1981), "the basic skills in communication are built upon the dominant functions of language in its social uses." Thus, the essence of pragmatic theory is that language is used functionally, to accomplish specific types of commication.

A number of researchers have examined the functions of communication in children's speech (Jacobson, 1960; Bruner, 1975; Halliday, 1975; Wood, 1981). One such communicative function is referred to as the informative function (Halliday, 1975; Hopper and Naremore, 1978; Wood, 1981). The informing function occurs when a speaker provides ideas and information to others, as in describing, naming, and giving examples, as well as when a listener responds to information given by others such as in answering, questioning and denying (Wood, 1981). According to Halliday (1975), a speaker must 
internalize a whole set of complex linguistic concepts before he can use language as a means of communicating new information to a listener. What has not been make clear is when children become competent in making specific, clear statements when describing a referent or event.

According to Krauss and Glucksberg (1969), a speaker must perform two analyses when communicating information to a listener. First, the speaker must analyze the characteristics of the referent he intends to describe, so that his message will take into account those attributes of the referent which distinguish it from nonreferents. Secondly, the speaker must make an analysis of the listener, so that a message may be formulated which is compatable with the listener's knowledge and capabilities. A number of studies have focused on the first of these two analyses (Krauss and Glucksberg, 1969; Glucksberg, Krauss and Higgins, 1975; Ford and Olson, 1975; Whitehurst, 1976).

In 1969, Krauss and Glucksberg createc a communication game in which children were required to describe an abstract form to another child, who was asked to identify the abstract form from this description. It was found that the communicative accuracy of the descriptions improved with age. This study has been criticized, however, due to its use of abstract forms which differed on undefined attributes (Whitehurst, 1976).

In a study conducted by whitehurst (1976), children were required to describe to an adult listener which cup 
contained a marble. On the basis of this description, the listener was instructed to point to the correct cup. The cups varied in size, color, and design attributes. As part of the procedure in this study, the listener always picked the correct cup regardless of the child's description, thus, only the child's baseline level of communication skills were assessed.

No study to date, found by this writer, has provided a detailed analysis of the changes that may occur in baseline descriptive strategies when children are placed under pressure to provide more information. Moreover, no study found by this writer has used common concrete referents, such as animals or food, as stimuli for measuring children's descriptive communication. Such data could provide additional insight into children's descriptive abilities at different stages of development.

\section{Statement of Purpose}

This study was designed to determine how pressure to provide more information affects referential communication in children of different age levels. The investigation will seek to answer the following questions:

1. Does referential communication vary, under pressure among four, six and eight year old children?

2. How do four, six and eight year old children's descriptions vary when they are pressured to provide more information? 
Definitions

Communicative Competence: the speakers ability to use language in ways that are appropriate to the situation (Hymes, 1971).

Contrastive Communication: for the purposes of this study, refers to responses which contain what is necessary to distinguisin a referent from nonreferents.

Distinctive Characteristics: serving to distinguish (Webster's Seventh New Collegiate Dictionary, 1961). For the purposes of this study, distinctive characteristics refers to those characteristics of the four stimulus pictures, within each of the five categories, which distinguish them as different from the other pictures within the same category (e.g., fruits; banana = yellow, cresent $/ \mathrm{moon}$ shaped, etc.; cherries = red, round, etc.).

Incomplete Communication: for the purposes of this study, refers to responses which contain less than what is necessary in order to distinguish a referent from nonreferents.

Informing Function of Language: the provision of ideas and information to others (Wood, 1981).

Language Content: nonverbal ideas or cognitions; an individual's observations, integrations, and generalizations of environmental events (Daniloff et al., 1980). Language content represents those things individuals talk about or understand in messages from others (Bloom and Lahey, 1978).

Language Structure: the way in which sounds, syllables, words, phrases and sentences are ordered and structured so that they can represent the content of speech. Language structure provides a way in which to talk about something (Daniloff et al., 1980).

Language Use or Function: the pragmatic aspect of language; communication in the social interactions of humans (Bates, 1976). Language function represents the reasons why individuals speak (Daniloff et al., 1980).

Pragmatics: a set of rules governing the use of language in social contexts (Bates, 1976).

Pressure: the influence or force to make someone do something (Webster's Seventh New Collegiate Dictionary, 1961). For the purposes of this study, the "influence" or "force" refers to the child being asked to redescribe, leading to the child's perception of being in error. 
Referential Communication: the ability to use a word for a particular event, object, or relationsinip wich the word represents in specific context; it involves constructing a message that erables someone else to know to what the message is referring (Allen and Brown, 1976).

Repetitive Communication: for the purposes of this study refers to a response which is a repetition of a description of a referent.

Speech Act: a unit of linguistic communication which is expressed according to srammatical and pragmatic rules and which functions to convey a speakers conceptual representations and intentions (Dore, 1974). 


\author{
CHAPTER II \\ REVIEW OF THE LITERATURE
}

\title{
$\underline{\text { Pragmatics }}$
}

One of the most fundamental aspects of language is that it is a social phenomenon. Humans use language to communicate and their conversations are set in specific physical and social context. The most perfectly constructed sentence will not be effective unless it is used within the proper context (Dale and Ingram, 1981). Consequently, being appropriate to the situation is not some optional extra in language, but rather an essential element in the ability to mean (Halliday, 1978). As de Villiers and de Villiers (1978) observe: "a child with impaired articulation does not seem nearly as disordered as one whose speech is perfectly pronounced but often noncommunicative and inappropriate to the situation."

Pragmatics has been defined as the study of rules for using language in context (Bates, 1976). Within the past decade there has been an emerging interest in the area of pragmatics, with emphases in both linguistic theory and the study of child language. To date, however, there is no overall theory that unifies the several aspects of language use that has been labeled pragmatics (Dale and Ingram, 1981). Rather, within the general domain of pragmatics, there are several 
closely related subdomains which consider aspects of language in context but at different levels of analysis and with different emphases. Thus far, the two most intensively studied pragmatic subdomains include: (1) the speech acts or intentions that are performed with words (Searle, 1969; Austin, 1962; Dore, 1975; Garvey, 1975) and (2) the functions that speech acts serve in meeting the needs of individuals (ErvinTripp, 1977; Halliday, 1975; Hopper and Naremore, 1978; Wood, 1981).

Within the literature on pragmatics, the terms function and speech acts have not been clearly differentiated, and are often used interchangably. According to Dore (1974), a speech act is a "unit of linguistic communication which is expressed according to grammatical and pragmatic rules and which functions to convey a speaker's conceptual representations and intentions." Communicative strategies appear to be what others have described as speech acts (Hopper and Naremore, 1978; Wood, 1981). Wood (1981), however, included nonverbal communication in addition to verbal communication in her discussion of communicative strategies. According to Dale and Ingram (1981), "the functions of language are also referred to as speech acts" although Prutting (1979) differentiated between the two when she stated, "speech acts only describe what the speaker intends by his message while functions include the listener's response."

To add to this confusion, both speech acts and functions have been analyzed and classified according to various 
linguistic categories, with each analysis differing somewhat depending upon the author's purpose, data, and philosophical point of view (Austin, 1962; Searle, 1969; Halliday, 1973; Bates, 1976). While a universal definition of both terms does not yet exist, it appears that speech acts are words wich represent an individual's intentions and meet his social needs by enabling him to accomplish various communicative functions. Consequently, both speech acts and the functions that these acts serve play a fundamental role in the achievement of communicative competence.

\section{Aspects of Communicative Competence}

Communicative competence is essential for social, personal and educational growth. iiymes (1971) describes communicative competence as the speaker's ability to use language in ways that are appropriate to the situation. Unlike linguistic competence, communicative competence involves an awareness of the transactions that occur between people. Competence, in this perspective, is tied to the actual performance of language in social contexts (Connolly and Bruner, 1974). According to Allen and Brown (1976), competence is characterized oy four principle features: (1) competence depends on experience in acquiring a number of communicative strategies that may be used to accomplish various social functions; (2) competence requires that an individual learn how to apply the most appropriate strategy for the situation; (3) competence is revealed when strategies used accomplish a 
a certain intent; (4) competence is sustained when individuals are able to evaluate their strategies in terms of appropriateness to the communication context and their interpersonal effectiveness. Researchers in child language have stuaied early pragmatic behavior in an attempt to determine how communicative competence äevelops. From these studies, various classification systems have been proposed to aid in the analysis of children's speech behavior (Austin, 1962; Iiymes, 1971; Bruner, 1975; Halliaay, 1975; Bates, 1976).

As an early communicator, the infant, vocally and nonverbally, unwittingly affects listeners with such benaviors as gazing, crying, cooing, touching, grasping and vocalizing. Bates (1976) has described this behavior as perlocutionary acts; that is, acts which bring about an effect on the listener. It is not until approximately nine months that an infant generates illocutionary acts which, according to Austin (1962), are acts that function to accomplish a specific intent. These illocutionary acts can be evidenced by the child's pointing, giving, and showing. As a child moves into tine one-word stage he continues to intentionally affect his listener, using both verbal and nonverbal strategies (3loom and Lahey, 1978; Prutting, 1979).

Numerous researchers have attempted to examine early speech acts and the functions they serve by studying children's spontaneous speech. Consequently, a number of different frameworis for an analysis of the functions of language have been proposed (Piaget, 1926; Jacobson, 1960; Halliday, 
1973; Wood, 1981). While these functional frameworks employ äifferent categories and use äifferent terms, all cover essentially the same data. All resarchers, however, do not include every category in their classifications. Halliday's (1973) classification provides the framework for the following summarization.

One function, the instrumental function, refers to the fact that language allows a speaker to accomplish things (Halliday, 1973). A cinild becomes aware that he can ask for things and cause things to happen through words alone (wardhough, 1976). Language, in this context, serves the function of satisfying material neeas (Halliday, 1973).

Language as an instrument of cointrol has another side to it, since the child is vell aware that language is also a means whereby others exercise control over him. Closely related to the instrumental model, therefore, is the secona function called the regulatory function of language. This refers to the use of language to regulate the behavior of others (Halliday, 1973). Thus, while the instrumental function of language relates to shaping the chila's whole worla, the regulatory function relates solely to manipulation. Jacobson (1960) calls this the conative function, while wood (1981) refers to it as the controlling function of language. Piaget (1926) views the regulatory function as a characteristic of socialized speecin in which the chilo tries to influence nis listener. These categories are defined by the various authors as follows: 
Regulatory - to exert control over the behavior of others (Halliday, 1973).

Conative - to persuade and influence others through commands and entreaties (Jacobson, 1960).

Controlling - involves attempts to direct or affect the behavior of others, as well as responses to control (Wood, 1981).

Socialized Speech - occurs when the child addresses his hearer, ... tries to influence, ... (Piaget, 1926).

A third function, the interactional function, refers to the use of language in the interaction between the self and others (Halliday, 1973). Jacobson's (1960) classification entitled phatic communication can be considered a part of the interactional function, in that it includes those small "meaningless" exchanges which indicate a channel of communication is open, should it be needed. According to wardhaugh (1976), successful interaction requires good "manners," saying things appropriately and doing things in the prescribed way. Thus, Wood's (1981) ritualizing function and Piaget's (1926) social phrases can be viewed as similar to Halliday's (1973) interactional classification. Specific definitions are as follows:

Interactional - to establish and maintain contact with those that matter to him (Halliday, 1973).

Phatic - to establish an atmosphere for communication with others (Jacobson, 1960).

Ritualizing - to help sustain our social relationships; greeting, thanking, introducing (Wood, 1981).

Social Phrases - occur only in social situations; please, thank you, hi, bye (Piaget, $1926)$. 
A fourth function, Halliday's (1973) personal function and Jacobson's (1960) emotive function refer to the child's awareness of language as a form of his own individuality. According to Halliday (1973), language for the child is very much a part of himself and the personal model represents the way in which the child expresses his individuality. Wood's (1981) sharing feelings classification can also be included within this framework. In addition to, and closely tied in with the expression of individuality, language also provides the child with a means to express feelings. These categories are defined as follows:

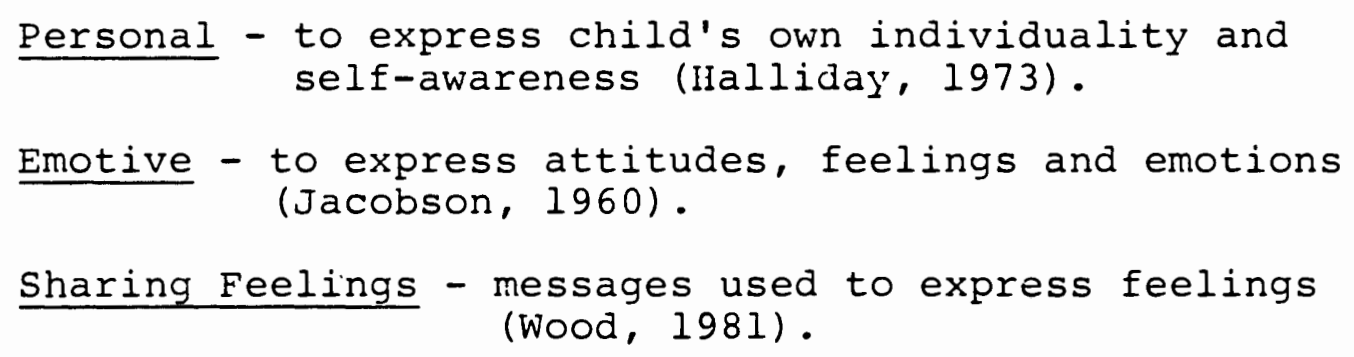

A fifth function, the heuristic function, refers to language as a means of investigating reality; a way of learning about things (fialliday, 1973). According to Halliday (1975), language allows the child to ask questions about the nature of his world and to construct possible answers. Piaget's (1926) functional model coincides with Halliday's (1973) heuristic model in that the question category of Piaget's socialized speech classification includes any remark that definitely requires an answer from the listener. Specific definitions are as follows:

Heuristic - to ask about the environment (Halliday, 1973). 
Questions - a form of socialized speech: any remark that definitely requires an answer from the hearer (Piaget, 1926).

A sixth function, Halliday's (1973) and Wood's (1981) imaginative function is not necessarily 'about' anything at all. That is, the child's linguistically created environment does not have to be a make believe copy of the world, occupied by people, things and events. Rather, it can be language used for the sheer joy of using language as in babbling, chanting, rhyming, etc. (Halliday, 1973). Jacobson's (1960) poetic classification may also be included within the imaginative framework since it involves indulging in language for the sheer pleasure of it. Perhaps Piaget's (1926) classification of egocentric speech can also be included within the imaginative framework. According to Piaget (1926), within this category "the child repeats words and syllables for the pleasure of talking, with no thought of talking to anyone nor even at times saying words that will make sense." Each category is defined by the various authors as follows:

$$
\begin{aligned}
& \begin{array}{c}
\text { Imaginative - to play act and thus pretend (Halliday, } \\
1973) \text {. }
\end{array} \\
& \begin{array}{r}
\text { Imagining - involves dealing creatively with reality } \\
\text { through language (Wood, 1981). }
\end{array} \\
& \begin{array}{r}
\text { Poetic - to indulge in language for its own sake (Ja- } \\
\text { cobson, 1960). }
\end{array} \\
& \begin{aligned}
\text { Egocentric speech - the child talks either for himself } \\
\text { or for the pleasure of associating } \\
\text { any one who happens to be there } \\
\text { with the activity of the moment } \\
\text { (Piaget, l926). }
\end{aligned}
\end{aligned}
$$

Finally, the representational or informative function 
of language refers to the use of language in communication; i.e., to provide ideas and information to others (Halliday, 1973; Wood, 1981). The child becomes aware that he can convey a message in language, a message which has specific reference to the processes, persons, objects, abstractions, qualities, states and relations of the world around him (Halliday, 1973). Jacobson (1960) calls this the referential function, while Piaget (1926) considers it part of socialized speech. According to Halliday (1975), the informative function is undoubtedly dominant in the adult's use of language; however, it does not begin to emerge in the life of a child until after the other functions have been established at approximately 21-22 1/2 months. Fach category discussed is defined as follows:

Representational or Informative - to communicate experience not shared by the hearer (Halliday, 1973).

Informing - occurs when we provide ideas and information to others (Wood, 1981).

Referential - to convey messages and information ( Jacobson, 1960).

Adapted Information - a part of socialized speech where the child exchanges his thoughts with others (Piaget, 1926).

It should be pointed out that functional classifications are not limited to those discussed above. Rather, numerous other frameworks, both verbal (Dore, 1974, 1975; Tough, 1977; Greenfield and Smith, 1976) and nonverbal (Bates, 1976; Coggins and Carpenter, 1978) have been postulated. As previously mentioned, the categories are somewhat diverse; 
however, upon close examination one can determine four categories from the previous discussion which all functional frameworks appear to have in common. These include: controlling, interacting, imagining and informing.

It should also be mentioned that all the functions are not discrete. As a child becomes older language functions tend to overlap. Speaking is a complex activity which proceeds on more than one plane at a time. Thus, a single brief exchange can be made to serve more than one function (Wardhaugh, 1976).

It appears that a child's awareness of language cannot be isolated from his awareness of language function; that is, his awareness of how language is used in different circumstances. Children must learn not only the sounds and grammatical forms of language, but also how to use these sounds and forms appropriately. Exactly when children are able to use language competently to accomplish specific functions has not yet been established.

\section{Referential Communication}

One important aspect of the informing function of language is the process of referential communication. Referential communication is the ability to use a word for a particular event, object, or relationship that the word represents in specific contexts; it involves constructing a message that enables someone else to know to what the message is referring (Allen and Brown, 1976). Referents may be particular stimuli 
or classes of stimuli. A referent may be referred to with any one of a number of different names and a single name may refer to any one of a number of referents (Glucksberg and Irrauss, 1967). As Rosenberg and Cohen (1966) have pointed out, the "correct" name for a referent in one context may be "incorrect" in another. Thus, the attribute "correct" is used here to indicate that a particular name is useful in talking about a referent; it enables a listener to understand a speaker in a given context.

In general, a listener is said to understand a speaker if he can correctly discriminate the referent from a set of nonreferents on the basis of the message supplied by the speaker (Glucksberg and Krauss, 1967). For example, if a particular dog is the referent, it may be called a golden retriever, bird dog, canine, the dog with the golden hair, or by a given name such as Cassidy. Clearly, each of these names could be "correct" in some contexts and "incorrect" in others depending upon the particular nonreferents involved, the general context of the conversation, and the particular listener (Krauss and Glucksberg, 1969).

There are circumstances when the most usual name for something fails to specify the referent. The most usual name for a particular kind of vehicle may be "car," but that word would have little discriminating value to the attendant at a parking ramp. Similarly, an adequate reference for one person may not be adequate for another. One might use the word "reinforcement" to refer to a food pellet when talking to an 
experimental psychologist, but one might use the word "reward" when talking with a young child. These few examples suggest that the task of selecting specific words to suit particular social and physical contexts may not be a trivial one and that learning how to do so may pose formidable developmental problems to be solved as children learn how to use their language effectively (Glucksberg et al., 1975).

Piaget (1926) recognized the development of referential skills in children by distinguishing between egocentric and socialized speech. Speech was regarded as egocentric when the speaker did "not attempt to place himself at the point of view of the hearer." Socialized speech, in contrast, occurs when the speaker considers the listener's comprehension and modifies his verbalizations accordingly.

On the basis of his observations and classifications of children's language in free play interactions, Piaget (1926) reached certain conclusions concerning the transitions from egocentric to socialized speech. There has, however, been much controversy over Piaget's results. Attempts to establish reliable measures of categories have been unsatisfactory (McCarthy, 1954); there have been widely divergent estimates of the proportions of egocentric and socialized speech in children's language as well as of the different ages at which the transition between the two stages presumably occurs (Tough, 1977).

An alternative approach to the study of referential communication as an interpersonal skill is to arrange tasks 
in which speakers are assigned explicit referents to communicate to listeners, and listeners are given the task of identifying speaker's referents from the speaker's utterances. This experimental paradigm was developed to aid in investigating the acquisition and growth of referential communication skills. Examples of this approach to referential communication development in children includes experiments reported by Glucksberg, Krauss and Weisberg (1966), Glucksberg and Krauss (1967), Rosenberg and Cohen (1966), Cohen and Klein (1968), Krauss and Glucksberg (1969), Peterson, Danner and Flavell (1972), Ford and Olsen (1975), and Whitehurst (1976). In these investigations, various stimulus arrays have been utilized.

One series of studies focused on the speaker's descriptions of novel graphic forms (Glucksberg et al., 1966; Glucksberg and Krauss, 1967; Krauss and Glucksberg, 1969; Fishbein and Osborne, 1971; Peterson et al., 1972). In 1966, Glucksberg et al., employed a communication task in which visually separated speaker-listener pairs in the four to five year age range were instructed to communicate about novel graphic forms. They found that these child dyads were incapable of adequate communicative performance with these stimuli. Using the same procedure as Glucksberg et al., (1966), Krauss and Glucksberg (1969) examined referential cominication ability with children in kindergarten, first, third, and fifth grades. Results showed that matched age pairs differed little on first trials, but varied in the rate at which they 
decreased errors as a function of grade level;i.e., kindergartener's showed no improvement over eight trials.

Other studies utilizing the Glucksberg et al. (1966) communication task added a feedback variable to their investigations. In a study done by Glucksberg and Krauss (1967), the listener supplied the subjects with the feedback "I don't understand you" following each description. Results showed an increase with age in the amount of appropriate post-feedback modification; that is, the younger children did not reformulate their initial descriptions to provide additional information, whereas the older children did.

In a study conducted by Peterson et al. (1972), children four and seven years of age were asked to describe nonsense figures to a listener. Half of each age group were male and half were female. The listener provided the speakers with one of the following forms of feedback: (1) nonverbal; (2) explicit, e.g., "Can you tell me anything else about it"; and (3) implicit, e.g., "I don't understand." Both four and seven year old children reformulated their initial messages when explicitly requested to do so by the listener, and both failed to reformulate when confronted only with nonverbal, facial expressions of noncomprehension. In contrast, only seven-year-olds tended to reformulate their messages in response to an implicit rather than an explicit verbal request for additional information. Sex was not found to be a significant factor.

In 1971, Fishbein and Osborne demonstrated that care 
should be taken when generalizing age or grade related performance differences. In their investigation, first and fifth grade speakers participated in a communication task (Glucksberg et al., 1966) with either first or fifth grade listeners. The relative performances of first and fifth grade pairs varied as a function of knowledge of the results. For instance, when feedback conditions were held constant, fifth-graders performed better than first-graders. However, first-graders under "optimal" feedback conditions do as well as fifth-graders under "less optimal" conditions. These results indicate that the relatively poor performance of young children may be, at least in part, situation-bound.

It appears that the capacity to communicate referentially is a function of age as well as a function of the situational conditions involved. It should be pointed out, however, that the age related performance differences may at least be partially attributed to the use of novel forms as stimuli. Because novel forms differ on undefined attributes, an individual will most likely base his description of these novel forms on past experience. According to Alexander (1969), "where the context is not clear, we tend to grope hurriedly through our past experiences to try to pin down some plausible range of meaning that will fit the symbols to the context at hand." What an individual perceives is the result of his personality, his environment, and his history filtered through his experiences (Bois, 1978). Perhaps lack of experience rather than lack of referent communication skills is 
the reason why younger children do not describe novel forms as well as older chilaren do.

In 1968, Cohen and klein conducted a referent communication investigation which focused on the use of a word-communication task. In this task, subjects (forty boys and forty girls) were studied in speaker-listener dyads. Speakers and listeners were simultaneously, but separately, presented with the same pair of stimulus words. One of the stimulus words was designated for the speaker as his referent, and his task was to provide a new one-word clue that would indicate to his listener which of the two stimulus words was the referent. The listener's task was to choose the referent word on the basis of the speaker's clue. Using subjects in third, fifth and seventh grades, Cohen and Klein (1968) found that communication accuracy increased as grade level increased. The authors, however, did consider the possibility that the deficient performance of their younger subjects was attributable to limitations in their vocabulary. No significant effects were demonstrated for sex or for the interaction of grade level and sex.

In a study conducted by whitehurst (1976), kindergarten, first, second and fourth grade children (four boys and four girls from each grade level) were required to describe to an adult listener which cup contained a marble. On the basis of this description, the listener was instructed to point to the correct cup. The cups varied in size, color and design attributes. As part of the procedure in this 
study, the listener always picked the correct cup regardless of the child's description thus, only the child's baseline level of communication skills was assessed. The children's responses were scored as either incomplete communication, in which the child said less than necessary in order to distinguish a referent from a nonreferent; redundant communication, in which more is said than necessary to be informative; and contrastive communication, which is informative and non-redundant. The authors found that incomplete responses decreased with age and that communication became more redundant, rather than contrastive, over the early school years. No significant effects were found for sex.

of all the referent communication investigations found by this writer, none have utilized common concrete referents, such as animals or foods, as stimuli for measuring children's referent communication skills. In addition, no study found by this writer has provided a detailed analysis of the changes that may occur in baseline descriptive strategies when children are placed under pressure to provide more information. Such data could provide additional information and insight into children's referential communication skills at different levels of development. 


\section{METHODS AND PROCEDURES}

\section{Selection of Subjects}

Eighteen children drawn from an elementary school or a preschool in the Portland metropolitan area served as subjects. Letters of permission (Appendix A) were sent home to all children in a randomly chosen first and third grade class in the elementary school, and to fifteen four year old children in the preschool. One week was allowed for these permission slips to be returned. From the letters returned, six children were randomly chosen from each age level to be screened for participation in the study.

\section{Screening Instrumentation}

Subjects were screened by utilization of the following instruments :

1. A portable pure-tone audiometer (Beltone, model $10 \mathrm{D})$

2. The Peabody Picture Vocabulary Test - Revised (PPVT-R), form L (Dunn, 1981)

3. An animal picture (Level P, \#A2) from Peabody Language Developmental kits (Dunn, Horton and Smith, 1968)

Experimental Instrumentation and Stimuli 
Five categories (fruits and vegetables, animals, shoes, transportation, and kitchen items) of pictures made up of common referents were used as stimuli. Eight pictures were used for each category and were divided into two sets of four pictures each. Both sets of pictures within each category were analyzed according to critical features. The two pictures in each set which had the most similar features were noted; i.e., same shape, color, size, etc. All of the pictures used in the study (See Appendix B) were from Peabody Language Developmental Kits (Dunn and Smith, 1965, 1966; Dunn et al., 1968). All experimental sessions were audiotaped by an Emerson AM FM cassette recorder, Model CTR-940.

\section{Screening Procedure}

For inclusion in the study, each subject met the following criteria:

1. Passed a pure-tone audiological screening examination, in one ear, at $25 \mathrm{dBHL}$ for the following frequencies: $500,1000,2000$, and $4000 \mathrm{~Hz}$

2. Attained a receptive vocabulary age within one standard deviation of the mean for their chronological age on the PPVT-R (Dunn, 1981)

3. Described an animal picture from Peabody Language Developmental Kits (Dunn, 1965) and were judged as intelligible by this investigator

All screening was completed in an empty classroom. Any child who failed any part of the screening was excluded from participating in the study and another child, from the same age level, was randomly chosen and screened for participation in the study. 


\section{Description of Subjects}

Chronological age and sex of the eighteen subjects (three groups of six) who passed the screening were as follows: six girls with a mean age of 4.3 ; three boys and three girls with a mean age of 6.5 ; and two boys and four girls with a mean age of 8.6 . Sex was not controlled for due to the fact that no significant sex differences have been found in previous referential communication studies (Cohen and Klein, 1968; Peterson et al., 1972; Whitehurst, 1976).

\section{Experimental Procedure}

The children were brought individually into an empty classroom by this investigator and seated at a table facing a female adult serving as a listener. The investigator explained to the subjects that they would be playing a game in which they would be asked to describe, without naming, one of four pictures to the listener. The children were told that if the listener identified the correct picture on the basis of their description, within two responses, they would receive a token. It was explained that ten tokens could be turned in for a prize at the end of the game (see Appendix C for verbatim instructions). All prizes were colorfully wrapped and placed within the child's sight throughout the study. Before the trials began, each child was asked to explain what they had to do in order to win a token. In addition, the child was asked to describe one of the sample 
pictures to the listener. If the child gave the correct explanation and described the picture without naming it, the game began. Otherwise, relevant instructions were repeated until understood. If a child pointed to the correct picture or named it, he was reminded he was supposed to tell the listener what the picture looked like, not what or where it was. If the child still did not perform the task following these instructions, he was excluded from participating in the study. During the trials, the listener sat facing the child with her eyes closed. The investigator arranged the first set of four pictures on the table, placing the two pictures with the most similar features next to each other. The investigator then pointed to one of these two pictures for the child to describe (See Appendix B). Following the child's description, the listener opened her eyes and regardless of the description given, pointed to the incorrect picture; the one with features most similar to the correct picture. (All pictures the listener was to pick were color coded in the extreme right corner.) The child was reminded that he could still win a token, and possibly the prize, if the listener could guess the correct picture after one more description. Following the child's second description, the listener always selected the correct picture and the child was praised and given a token. During the study, all picture sets in each category were presented in random order for each child. Although the two pictures with the most similar features were always placed next to each other, their placement, in 
relation to the other two pictures in each set varied randomly for each trial. All experimental sessions were audiotaped and transcribed verbatim (See Appendix D).

\section{Data Scoring and Analysis}

This investigator recorded all the children's descriptions (both first and second trials) and scored each description as one of the following types of communication:

1. Incomplete Communication: responses which contain less than what is necessary in order to distinguish a referent from nonreferents

2. Contrastive Communication: responses which contain what is necessary to distinguish a referent from nonreferents

3. Repetitive Communicaiton: a response which is a repetition of a description of a referent

Two graduate students were selected from Portland state University speech and riearing Sciences Program to function as judges. Each category of communications was thoroughly explained to the judges, via verbal and written instructions (See Appendix E), along with examples of each. The judges were then asked to score independently the children's descriptions according to the three types of communications. A 93 percent inter-scorer reliability was obtained. Intra-judge consistency was found to be 100 percent when the same descriptions were scored by the investigator one week later and compared to the original scoring. The data were then statistically analyzed using two $2 \times 3$ ANOVAs (trial by age) with repeated measures on the trial factor. This analysis was used 
to assess the following:

1. Is there a main effect for age performance?

2. Is there a main effect between the first and second trial?

3. Is there an interaction effect between trials and age level? 
CHAPTER IV

RESULTS AND DISCUSSION

\section{Results}

The purpose of this investigation was to determine how pressure to provide more information affects referential communication in children of different age levels; specifically ages four, six and eight. Preliminary to analyzing the data, each child's descriptions, for both trial one and trial two, were scored as one of the following types of communication: incomplete, contrastive or repetitive. All scores and subject information are included in Appendix F.

The first question posed was: Does referential communication vary, under pressure, among four, six and eight year old children? The results of this study revealed referential communication did vary, under pressure, among the four, six and eight year old children.

In order to describe the results, background information is appropriate regarding the statistical treatment. A visual inspection revealed repetitive communication was used by the four year old age group only and therefore did not lend itself to statistical analysis. The raw performance data for incomplete and contrastive descriptions were tabulated and analyzed using an Analysis of Variance, Two-Factor 
Mixed Design for Repeated Measures on One Factor (Bruning and Kintz, 1977). The results of this analysis revealed, for both incomplete and contrastive descriptions, a significant main effect in age performance ( $p<.001)$, a nonsignificant main effect for performance within trials $(p<.1)$, and a nonsignificant interaction effect between age and trial ( $p<2)$. The Analysis of Variance scores for all sources were identical for both the contrastive and incomplete variables due to the fact that incomplete and contrastive are complimentary variables, scored on a base of ten, i.e., a contrastive score of eight would insure an incomplete score of two for a total of ten (Tables I-IV).

Because there was a significant main effect for the age variable, the Scheffé post hoc test was performed to determine where the significant differences in age group performance across trials occurred. The results of this test indicate a significant difference $(p<.05)$ between four and eight year old children's descriptions only, with contrastive means of 3.33 for the four year olds, 4.58 for the six year olds, and 7.0 for the eight year olds, and incomplete means of 6.67 , 5.42 , and 3.0 respectively (Tables $V$ and VI). A visual inspection of age group means (Table VII) revealed similarities between the four and six year old children's contrastive and incomplete descriptions in trial two. Due to these trial two similarities, any significant group differences for trial one may have been cancelled out. Consequently, $t$ tests for differences between two individual means were performed 
TABLE I

ANALYSIS OF VARIANCE FOR CONTRASTIVE DESCRIPTIONS

\begin{tabular}{|c|c|c|c|c|c|}
\hline Source of Variation & SS & $d f$ & MS & $\mathrm{F}$ & $\mathrm{P}$ \\
\hline Total & 194.97 & 35 & & & \\
\hline $\begin{array}{l}\text { Between Subjects } \\
\text { Conditions } \\
\text { Error } b\end{array}$ & $\begin{array}{r}120.47 \\
83.38 \\
37.09\end{array}$ & $\begin{array}{r}17 \\
2 \\
15\end{array}$ & $\begin{array}{r}41.69 \\
2.47\end{array}$ & 16.88 & $.001 *$ \\
\hline $\begin{array}{l}\text { Within Subjects } \\
\text { Trials } \\
\text { Trials x Conditions } \\
\text { Error }\end{array}$ & $\begin{array}{l}74.5 \\
12.24 \\
10.53 \\
51.73\end{array}$ & $\begin{array}{r}18 \\
1 \\
2 \\
15\end{array}$ & $\begin{array}{r}12.24 \\
5.27 \\
3.45\end{array}$ & $\begin{array}{l}3.55 \\
1.53\end{array}$ & $\begin{array}{l}.1 \\
.2\end{array}$ \\
\hline
\end{tabular}

* Significant

TABLE II

ANALYSIS OF VARIANCE FOR IINCOMPLETE DESCRIPTIONS

\begin{tabular}{|c|c|c|c|c|c|}
\hline Source of Variation & SS & $a f$ & I.SS & $F$ & $\mathrm{P}$ \\
\hline Total & 194.97 & 35 & & & \\
\hline $\begin{array}{l}\text { Between Subjects } \\
\text { Conditions } \\
\text { Error }\end{array}$ & $\begin{array}{r}120.47 \\
83.38 \\
37.09\end{array}$ & $\begin{array}{r}17 \\
2 \\
15\end{array}$ & $\begin{array}{r}41.69 \\
2.47\end{array}$ & 16.88 & $.001 *$ \\
\hline $\begin{array}{l}\text { Within Subjects } \\
\text { Trials } \\
\text { Triais x Conditions } \\
\text { Error }\end{array}$ & $\begin{array}{l}74.5 \\
12.24 \\
10.53 \\
51.73\end{array}$ & $\begin{array}{r}18 \\
1 \\
2 \\
15\end{array}$ & $\begin{array}{r}12.24 \\
5.27 \\
3.45\end{array}$ & $\begin{array}{l}3.55 \\
1.53\end{array}$ & $\begin{array}{l}.1 \\
.2\end{array}$ \\
\hline
\end{tabular}

* Significant 
TABLE III

RAI DATA ON CONTRASTIVE DESCRIPMIONS

WITH CELL TOTALS

\begin{tabular}{|c|c|c|}
\hline Age & Trial 1 Contrastive & Trial 2 Contrastive \\
\hline 4 & $\begin{array}{l}4 \\
6 \\
1 \\
4 \\
2 \\
2\end{array}$ & $\begin{array}{l}3 \\
4 \\
3 \\
4 \\
4 \\
3\end{array}$ \\
\hline Totals & 19 & 21 \\
\hline 5 & $\begin{array}{l}7 \\
3 \\
3 \\
8 \\
8 \\
5\end{array}$ & $\begin{array}{l}4 \\
5 \\
4 \\
2 \\
1 \\
5\end{array}$ \\
\hline Totals & 34 & 21 \\
\hline$\delta$ & $\begin{array}{l}8 \\
7 \\
7 \\
8 \\
9 \\
3\end{array}$ & $\begin{array}{r}5 \\
4 \\
4 \\
10 \\
7 \\
7\end{array}$ \\
\hline Totals & 47 & 37 \\
\hline
\end{tabular}


TABLE IV

RAW DATA ON INCOMPLETE DESCRIPTIONS

WITH CELL TOTALS

\begin{tabular}{|c|c|c|c|c|}
\hline Age & Trial & 1 Incomplete & Trial 2 & 2 Incomplete \\
\hline 4 & & $\begin{array}{l}6 \\
4 \\
9 \\
6 \\
8 \\
8\end{array}$ & & $\begin{array}{l}7 \\
6 \\
7 \\
6 \\
6 \\
7\end{array}$ \\
\hline Totals & & 41 & & 39 \\
\hline 5 & & $\begin{array}{l}3 \\
7 \\
7 \\
2 \\
2 \\
5\end{array}$ & & $\begin{array}{l}6 \\
5 \\
6 \\
8 \\
9 \\
5\end{array}$ \\
\hline Totals & & 25 & & 39 \\
\hline 8 & & $\begin{array}{l}2 \\
3 \\
3 \\
2 \\
1 \\
2\end{array}$ & & $\begin{array}{l}5 \\
6 \\
6 \\
0 \\
3 \\
3\end{array}$ \\
\hline Totals & & 13 & & 23 \\
\hline
\end{tabular}


TABLE V

SCHEFFÉ POST HOC TEST FOR AGE GROUP COMPARISON

OF CONTRASTIVE DESCRIPTIONS

(Trial 1 and Trial 2 Combined)

\begin{tabular}{ll|l}
\hline Age & $\overline{\mathrm{x}}$ score & \multicolumn{2}{|l}{ Difference Between Means } \\
\hline 4 years & 3.33 & Age 4 vs. Age 6: 1.25 \\
6 years & 4.58 & Age 4 vs. Age 8: $3.67 *$ \\
8 years & 7.0 & Age ó vs. Age 8: 2.42 \\
\hline
\end{tabular}

* Significant $(p<.05)$ since this value exceeds the critical value of 2.90

\section{TABLE VI}

SCHEFFÉ POST HOC TEST FOR AGE GROUP COMPARISON

OF INCOMPLETE DESCRIPTIONS

(Trial 1 and Trial 2 Comoined)

\begin{tabular}{ll|l}
\hline Age & $\bar{x}$ score & Difference Betiveen Means \\
\hline 4 years & 6.67 & Age 4 vs. Age 6: 1.25 \\
6 years & 5.42 & Age 4 vs. Age $6: 3.67 \star$ \\
8 years & 3.0 & Age 6 vs. Age $8: 2.42$ \\
\hline
\end{tabular}

* Significant $(p<.05)$ since this value exceeds the critical value of 2.90 
TASLE VII

A COIPARISON OF AGE GROUP MEAN SCORES AND

STANDARD DEVIATIONS FOR Trial $l\left(\mathrm{~T}_{1}\right)$ and Trial $2\left(\mathrm{I}_{2}\right)$

Contrastive Descriptions

\begin{tabular}{|c|c|c|}
\hline Age & $T_{1}$ & $T_{2}$ \\
\hline 4 & SD $\begin{array}{l}3.17 \\
1.83\end{array}$ & $\mathrm{SD}^{3.5} 0.55$ \\
\hline 6 & $\begin{array}{c}5.67 \\
S D 2.34\end{array}$ & $\begin{array}{c}3.5 \\
\text { SD } 1.64\end{array}$ \\
\hline 8 & $\begin{array}{c}7.83 \\
S D .75\end{array}$ & $\begin{array}{c}6.17 \\
\text { SD } 2.32\end{array}$ \\
\hline
\end{tabular}

Incomplete Descriptions

\begin{tabular}{|c|c|c|}
\hline Age & $\mathrm{T}_{1}$ & $\mathrm{~T}_{2}$ \\
\hline 4 & $\begin{array}{c}6.83 \\
\text { SD } 1.83\end{array}$ & $\begin{array}{c}5 . j \\
\text { SD } \\
0.55\end{array}$ \\
\hline 6 & $\begin{array}{c}4.33 \\
\text { SD } 2.34\end{array}$ & $\mathrm{SD}^{6.5} \mathrm{i}^{-64}$ \\
\hline \multirow[t]{2}{*}{8} & $\begin{array}{c}2.17 \\
\text { SD } 0.75\end{array}$ & $\begin{array}{c}3.83 \\
S D \quad 2.32\end{array}$ \\
\hline & \multicolumn{2}{|c|}{ Repetitive Descriptions } \\
\hline Age & $\mathrm{r}_{1}$ & $\mathrm{~T}_{2}$ \\
\hline 4 & & 1.83 \\
\hline 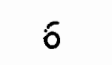 & & \\
\hline
\end{tabular}


separately for trial one and trial two, to determine if there were any significant age group differences which were not revealed by the scheffé post hoc test. The results of these $\underline{t}$ tests are summarized in Table VIII and indicate the following: In trial two, with added pressure, a significant difference was found between four and eight year old children's contrastive and incomplete descriptions ( $p^{<.025)}$ and six and eight year old children's contrastive and incomplete descriptions ( $p<.025)$, with contrastive means of 3.5 for both the four and six year olds, and 6.17 for the eight year olds, and incomplete means of 6.5 for both the four and six year olds and 3.83 for the eight year old children. In trial one, a significant difference was found between four and six year old children's contrastive and incomplete descriptions $(p<.05)$, four and eight year old children's contrastive and incomplete descriptions $(p<.005)$ and six and eight year old chilaren's contrastive and incomplete descriptions ( $\mathrm{p}<.05)$. The contrastive means were 3.17 for the four year olds, 5.67 for the six year olds and 7.83 for the eight year olds, and incomplete means were $6.83,4.33$, and 2.17 respectively. Thus, significant differences were found between all age groups with the exception of four and six year old children's contrastive and incomplete descriptions in trial two.

The second question posed was: How do four, six and eight year old children's descriptions vary when they are pressured to provide more information? This question was answered in two different ways. 
TABLE VIII

$t$ VALUES FOR DIFFERENCE BETIVEEIN PAIRS OF AGE GROUP ILEANS FOR CONTRASTIVE DESCRIPTIOINS

(Trial 1 anà Trial 2)

\section{TRIAL 1}

\begin{tabular}{lllll}
\hline Age Groups & $\bar{x}$ score & df & $t$ & $p$ \\
\hline 4 years vs. & 3.17 & 10 & -2.06 & $.05 *$ \\
6 years & 5.67 & & & \\
\hline 4 years vs. & 3.17 & 10 & -5.76 & $.005 *$ \\
8 years & 7.83 & & & \\
\hline ó years vs. & 5.67 & 10 & -2.16 & $.05 *$ \\
8 years & 7.83 & & & \\
\hline
\end{tabular}

* Significant

TRIAL 2

\begin{tabular}{lllll}
\hline Age Groups & $\bar{x}$ score & df & $t$ & $p$ \\
\hline 4 years vs & 3.5 & 10 & 0.00 & \\
6 years & 3.5 & & & \\
\hline 4 years vs. & 3.5 & 10 & -2.74 & $.025 *$ \\
8 years & 6.17 & & & \\
\hline 6 years vs & 3.5 & 10 & -2.30 & $.025^{*}$ \\
\hline years & 6.17 & & & \\
\hline
\end{tabular}

* Significant 
First, age group means were calculated for incomplete, contrastive and repetitive descriptions for both trial one and trial two (Table VII) and each trial was examined separately. In trial one, contrastive descriptions increased with age level, while incomplete descriptions decreased with age. Contrastive group means were 3.17 for the four year old children, 5.67 for the six year old children, and 7.83 for the eight year old children, while incomplete means were 6.83 , 4.33 and 2.17 respectively. In trial two, with added pressure, children of the four and six year old age group had an identical number of both contrastive (3.5) and incomplete (6.5) descriptions, while the eight year old age group, in comparison, used more contrastive (6.17) and less incomplete descriptions (3.83) than the four and six year old children. Repetitive descriptions (1.83) occurred in the four year old age group only (Figure 1).

Secondly, percentages of difference between trial one and trial two were compared for each age group (Table IX). These comparisons indicate only four year old children increased the number of contrastive descriptions when more pressure was added. The four year old children increased the number of their contrastive descriptions from 19 in trial one to 21 in trial two. Six year old children, however, decreased their contrastive descriptions from 34 in trial one to 21 in trial two, while eight year old children decreased contrastive descriptions from 47 in trial one to 37 in trial two. 

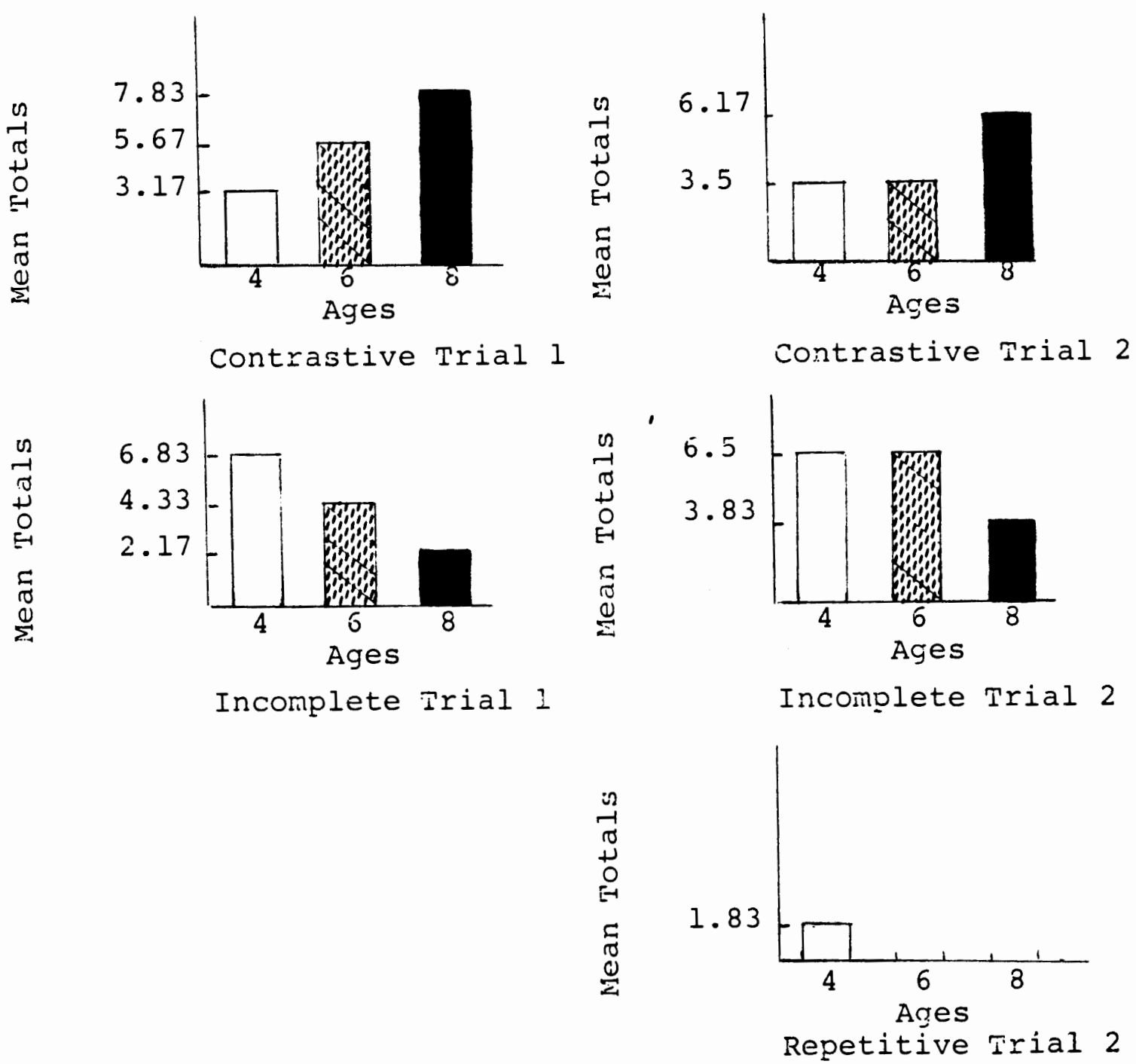

Figure 1. Illustration of the relationship between ages for contrastive, incomplete and repetitive descriptions within trials. 


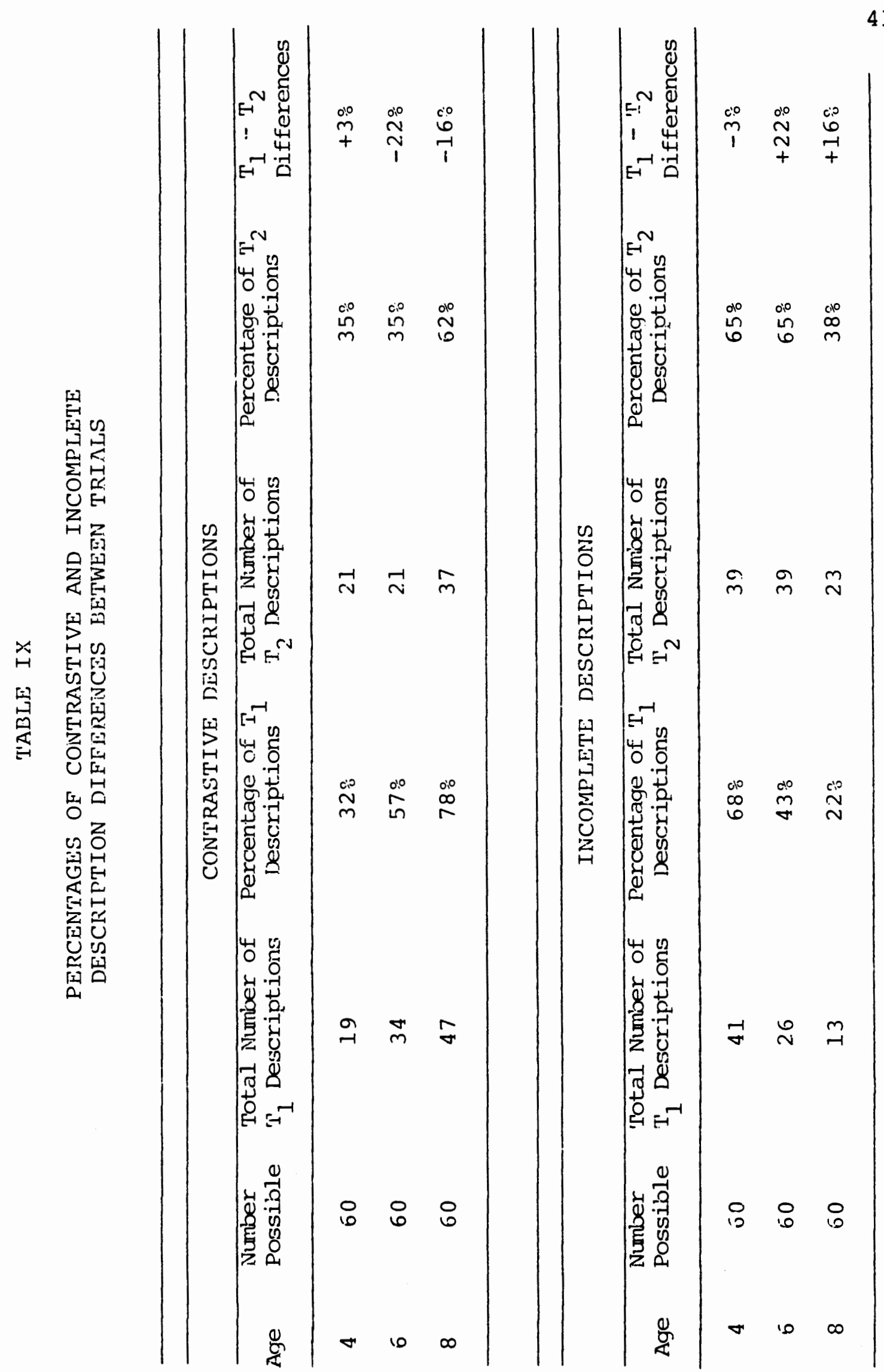




\section{Discussion}

The findings in this study relative to trial one, indicate that referential communication did vary in children aged four, six and eight and appeared to improve with age. This finding agrees with previous studies on referential communication discussed in chapter two (Krauss and Glucksberg, 1969; Glucksberg and Krauss, 1967; Peterson et al., 1972; Cohen and Klein, 1968). It appears that the younger children in this study had a tendency to describe objects in terms of such a generalized context of alternatives that they showed little sensitivity to the immediate context and to information that was actually and minimally required by the listener. Although the children may have known more information was needed, they may not have known how to give it. This agrees with a study done by Gallagher in 1977, in which children's revision strategies were examined. According to the results of Gallagher's (1977) study, as the child's knowledge of language structure develops, the ease with which he can employ any one of the revision options available to him increases. The development of revision strategies is, therefore not a process of narrowing response options to one strategy that can be regarded as being most successful, but rather more strategies become available as the child grows older. For example, the four year old children in the present study tended to describe the referents mainly in terms of color and noun attributes and used part or whole repetitions as their 
main revision strategy. In comparison, six and eight year old children's revision strategies, although not always contrastive, consisted of describing referents in terms of color, class, function, size and shape. Although few in number, relational terms were also used by the eight year old children (Appendix D).

In examining trial two, where pressure to provide more information was added, no variance was found between four and six year old children's descriptions, while eight year old children had a higher number of contrastive descriptions. Two possible rationales for these results involve Piaget's (1926) concepts of cognitive growth and egocentrism. In 1926, Piaget discussed stages in children's development of thinking. According to his stages, children between the ages of two and seven are in the Preoperational Intuitive Thinking Stage which is characterized by the following: consideration of elementary concepts of time, space and causality, a rudimentary concept of class and class inclusion, and an inability to utilize relational terms. For example, the preoperational child regards relational expressions such as "darker" in terms of absolute attributes of objects as opposed to relative attributes between objects, thus "darker" means very dark rather than darker than another object. Based on this premise, children four and six years of age would have difficulty giving contrastive descriptions, since being contrastive involves distinguishing attributes between objects. Perhaps similarities between 
four and six year old children's descriptions in trial two can be attributed to both age groups being in the Preoperational Intuitive Thinking Stage.

In comparison, Piaget (1926) considered children seven to eleven years of age to be in the concrete operational Thinking Stage, characterized by the following: an ability to classify objects according to a wide range of criteria related to size, shape, function and so forth, and an understanding of complex relationships resulting in an ability to utilize relational terms. The Concrete operational child has the capacity to solve problems by considering the relative relationships of the objects or events involved (Evans, 1973). Consequently, children eight years of age would consider the relationships between objects, which would enable them to be more contrastive in their descriptions than four or six year old children.

Also related to Piaget's (1926) cognitive stages is the concept of egocentrism. In 1926, Piaget discussed how difficult it is for a child to take the perspective of another person in a physical or social situation until he is approximately seven years of age. According to Piaget's (1926) concept of egocentrism, "the audience is disregarded" and the child "talks either for himself or for the pleasure of associating anyone who happens to be there with the activity of the moment." Perhaps egocentrism can be considered a reason why four and six year old children emitted a larger amount of incomplete responses than the eight year old children, in 
both trial one and trial two. In addition to disregarding the listener, the "egocentric" four and six year olds may have also disregarded the nonreferent picture stimuli used in this investigation, thus greatly reducing the possibility of emitting contrastive descriptions.

Another finding in this investigation revealed that only the four year old children demonstrated repetitive communication. In 1926, Piaget discussed repetition as being a type of egocentric speech. The four year old children in this study appear to have demonstrated this type of egocentrism. According to Piaget (1926), the egocentric child neither thinks about his own thinking nor attempts to consider any possible contradiction in his own thought processes. Consequently, when asked to once again describe the referent, as in trial two, the four year old children may not have considered the possibility that more information was needed. On the other hand, it is possible that the children of this age group simply lacked revision strategies, as suggested by Gallagher (1977), and thus, did not know how to give more information.

Still another finding revealed the percentages of difference between trial one and trial two (added pressure) for each age group. These percentages indicated that on 1 y the four year old age group increased their contrastive descriptions when more pressure was added, while the six and eight year old children increased incomplete descriptions. One possible reason for this unexpected finding may be explained 
by the anxiety level and "cautiousness" of the children. A theoretical model researched by Sarason, Davidson, Lighthall and Waite (1958) and discussed by Ruebush (1960) states: (1) defensive reactions such as cautiousness have been strongly overlearned and thus are stable "automatic responses" to the anxiety triggered by such situations as tests; (2) the effects of anxiety upon performance are mediated by these defensive reactions to the anxiety; (3) in problem solving situations where such defensive reactions are an asset, anxiety has a facilitating effect upon performance; and (4) in problem solving situations where such defensive reactions are a liability, anxiety has an interfering effect upon performance. Perhaps the older children in the present study could be considered as having high anxiety due to their previous experience with tests and thus, were too cautious. For example, when the listener did not select the correct picture in trial one, those children feeling high anxiety may have become cautious and thus changed their original description, even if they thought they had given the best description possible. In contrast, the four year old children may have felt less anxiety, due to having less experience in test situations, and thus were not as cautious, resulting in zero or minimal changes in their trial one descriptions. Consequently, in this situation, defensive anxiety reaction could have been a liability to the older children. It is also possible that the six and eight year old children were utilizing strategy changes in an effort to be successful at the task. 
It should also be mentioned that even though sex was not included in the original questions, it was examined post hoc. Although sex was not found to be a significant variable in previous referential communication studies (Cohen and Klein, 1968; Peterson et al., 1972; Whitehurst, 1976) it appeared to have an effect in this investigation. In the six year old age group, males showed a higher mean number of contrastive descriptions than females in trial one (males 7.0, females 4.0 ) and trial two (males 5.0, females 4.0). The four year old age group consisted of six females, thus a sex comparison could not be made. In the eight year old age group, males maintained a higher amount of contrastive descriptions (males 7.0 , females 5.75). In addition, a discrepancy was found between the male subject's low PPVT-R scores and their high number of contrastive descriptions (Figure 2). These data do not agree with the traditional literature which claims males have a less fluent command of language (Schuell, 1947; McCarthy, 1954; Dale, 1976). 


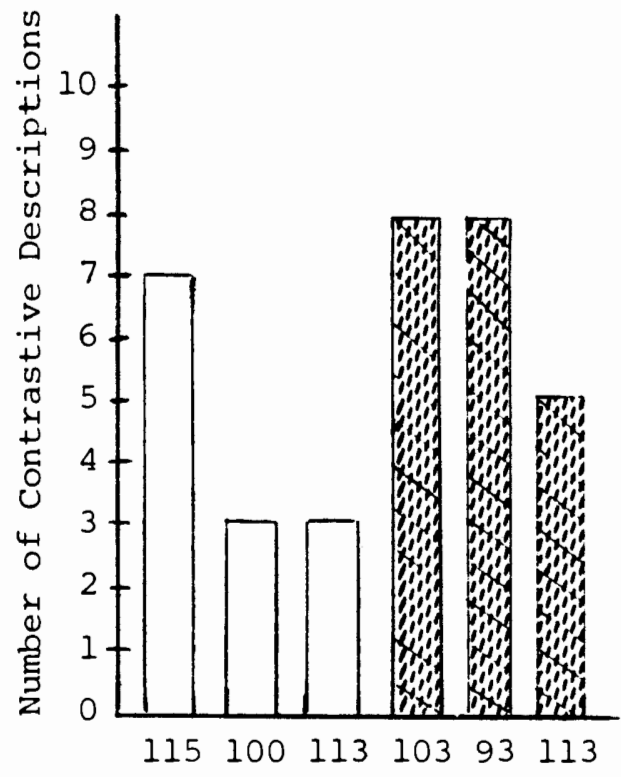

$$
\left(\mathrm{T}_{1}\right) 6.5 \text { years } \frac{\text { PPVT }-R}{\text { Scores }}
$$

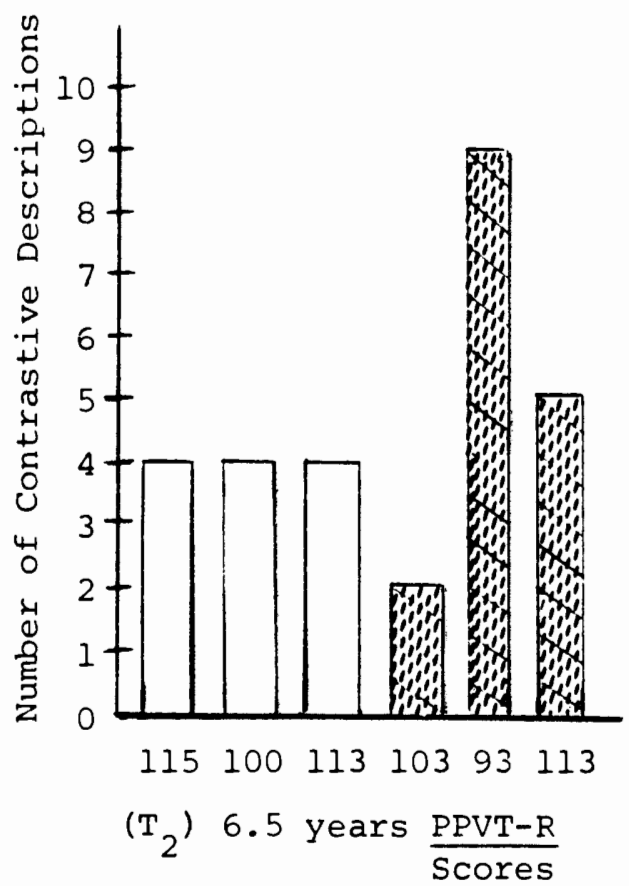

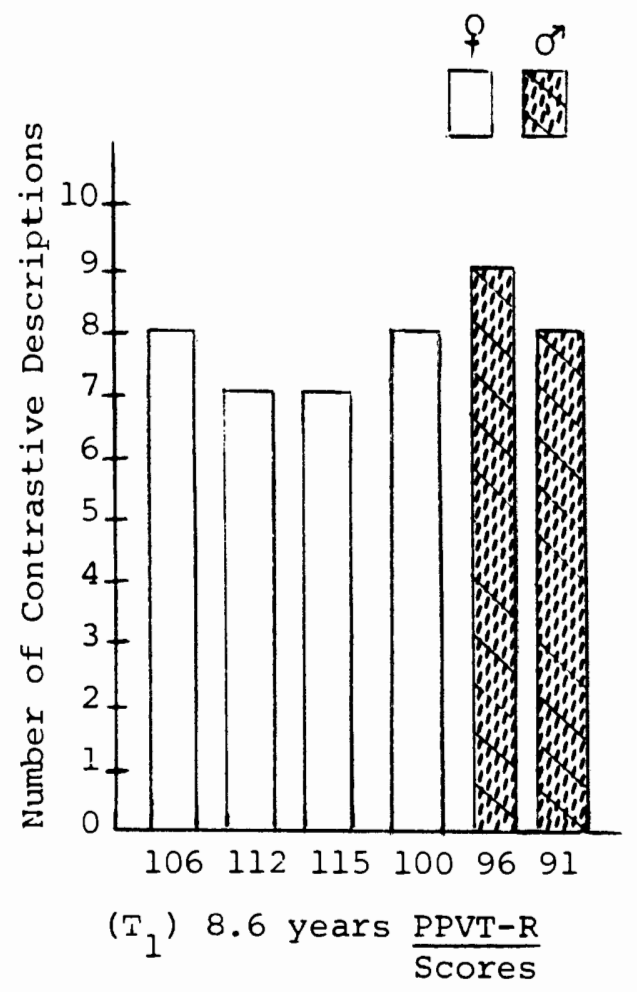

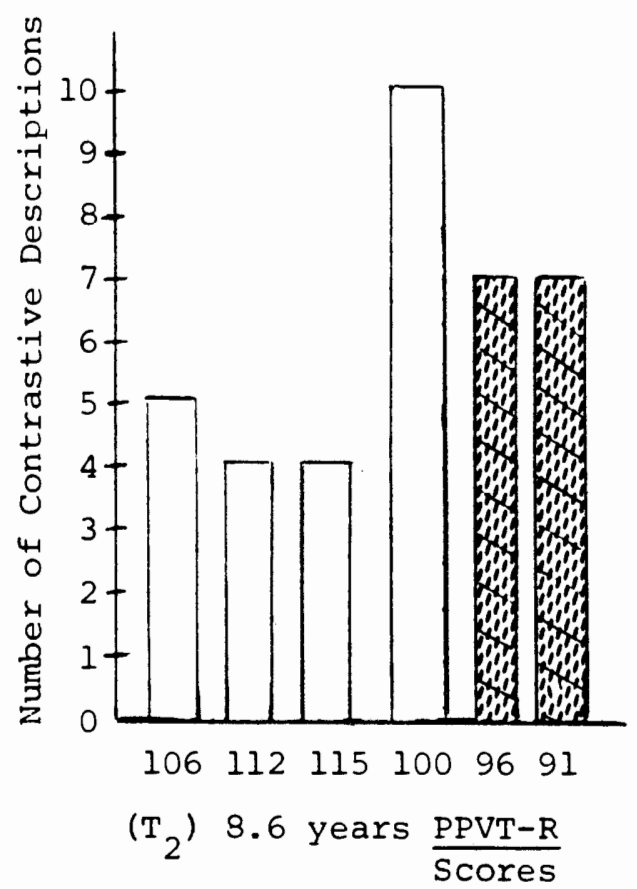

Figure 2. Illustration of sex difference and PPVT-R scores in Trial One $\left(\mathrm{T}_{1}\right)$ and Trial Two $\left(\mathrm{T}_{2}\right)$ contrastive descriptions. 


\section{CHAPTER V}

\section{SUMMIARY AND IMPLICATIONS}

\section{Summary}

Currently, language is viewed as a multi-dimensional construct, consisting of three interrelated components; content, form and function (Bloom and Lahey, 1978). In recent publications, language function has been referred to as pragmatics (Prutting, 1979). The essence of pragmatic theory is that language is used functionally in social contexts, to accomplish specific types of communication (Wood, 1981). One such communicative function if referred to as the informative function, which occurs when a speaker provides ideas and information to others, as in describing, naming and giving examples (Wood, 1981). It is not clear, however, when children become competent in making specific, clear statements when describing a referent or event. No study, found by this writer, has provided a detailed analysis of the changes that may occur in baseline descriptive strategies when children are placed under pressure to provide more information. Such data could provide additional insight into children's descriptive abilities at different stages of development. The questions posed in this investigation were:

Does referential communication vary under pressure among 
four, six and eight year old children? and (2) How do four, six and eight year old children's descriptions vary when they are pressured to provide more information?

Subjects were eighteen children, six from each age level, selected from an elementary and preschool in the metropolitan Portland area. A total of ten picture sets, each containing four pictures, was used in the investigation. Each subject was allowed two trials to describe one of the four pictures to a listener. The listener did not select the picture described until the second trial for all subjects. Each subject's description for trial one and trial two was scored as one of the following types of communication: incomplete, contrastive or repetitive.

The results showed significant differences, with added pressure, in trial two between four and eight and six and eight year old children's contrastive and incomplete descriptions, but nonsignificant differences between four and six year old children's contrastive and incomplete descriptions. In trial one significant differences were found between all age group's contrastive and incomplete descriptions. Repetitive communication occurred only in the four year old age group.

Results also revealed that, in trial one, contrastive descriptions increased with age while incomplete descriptions decreased with age. In trial two, however, children of the four and six year old age group had an identical number of both contrastive and incomplete descriptions, while the eight 
year old children, in comparison, emitted more contrastive descriptions than the four and six year old children. In addition, the results indicated that only the four year old children increased their contrastive descriptions when more pressure was added. It was speculated that these findings reflect, for the younger children, egocentric behavior and a lack of revision strategies. For the older children, it was surmised that added pressure resulted in high anxiety levels and strategy changes.

Although sex was not included in the original questions, it was examined post hoc and appeared to have an effect in this investigation. In the six and eight year old age group, males showed a higher number of contrastive descriptions than females in trial one and trial two. The four year old age group consisted of six females, thus a sex comparison could not be made.

\section{Clinical Implications}

From the results of this investigation, it appears that four year old children do not have sufficient cognitive skills to demonstrate competency in referential communication, while for six year old children, these skills appear to be in transition. Eight year old children, in comparison, appear to have the ability to describe adequately an object or event, and thus, seem to be competent in referential communication. It appears that referential communication develops with age. Therefore, early diagnosis and remediation of referential 
communication deficits may be in error and should be deferred until a child is cognitively able to demonstrate competence in this area. According to the findings in this investigation, this competency appears to occur sometime between six and eight years of age.

\section{$\underline{\text { Research Implications }}$}

If this investigation were to be replicated, or if further research in this area were to be explored, the following suggestions might aid the researcher:

(1) subjects of different age levels should be chosen to determine how referential communication changes with other age groups. It would be of particular interest to see if children seven years of age are as competent as the eight year old children in the present study, or if they are beginning to acquire these skills as the six year old children in the present study appeared to be; (2) sex should be a controlled variable in future referential communication studies since the present study seemed to indicate a sex difference; and (3) more information may be obtained by designing a study consisting of one trial rather than two. In the present study, the trial two "pressure factor" appeared to give added information on commicative strategies rather than referential communication.

Referential communication is not only important for academic learning, but also plays a large role in successful communication throughout everyday life. If this study were 
to be expanded upon, more information could be obtained which would not only enhance remediation strategies, but more importantly give clinicians a basis for knowing when remediation of referential skills would be most beneficial. 


\section{BIBLIOGRAP̈̈YY}

ALEXANDER, H.G., Meaning In Language. Illinois: Scott, Forman and Company, 1969.

ALLEN, R.R., and BROWN, K.L., Developing Cormunication Communication Competence In Children. Stokie, Illinois: National Textbook Company, 1976.

AUSTIN, J.L., How To Do Things With Words. New York: Oxford University Press, 1962 .

BATES, E., Language In Context. New York: Academic Press, 1976 .

BLOOM, L., and LAHEY, M., Language Development And Language Disorders. New York: John Wiley and Sons, 1978 .

BOIS, S.H., The Art of Awareness. Iowa: Wm. C. Brown Company publishers, 1978 .

BRUNER, J., The ontogenesis of speech acts. Journal of Child Language, 1975, 2, 1-20.

BRUNING, J.L., and KINTZ, B.L., Computational ilandbook of Statistics. Glenview, Illinois: Scott, Forman and Company, 1977 .

COGGINS, T., and CARPENTER, R., Categories for coding prespeech intentional communication. Unpublished manuscript, University of Washington, Seattle, 1978.

COIIEN, B.D., and KLEIN, J.D., Referent communication in school age children. Child Development, 1968, 39, 597609 .

CONNOLLY, K.S., and BRUNER, J.S., The Growth of Competence. New York: Academic Press, 1974.

DAIE, P.S., Language Development: Structure and Function. New York: Holt Rinehart and Winston, 1976.

DALE, P.S., and INGRAIA, D., Child Language: An International Perspective. Baltimore: University Park Press, 1981.

DANILOFF, R., SCHUCKERS, G., and FETH, L., Physiology of Speech and Hearing: An Introduction. Englewood Cliffs: Prentice Fall, 1980. 
de VILLIERS, J.G., and de VILLIERS, P.A., Semantics and syntax in the first two years. In F.D. Minifie and

L.L. Lloyd (Eds.), Communicative and Cognitive Abilities: Early Behavioral Assessment. Baltimore: University Park Press, 1978 .

DORE, J., A pragmatic description of early language development. Journal of Psycholinguistic Research, 1974, $3(4), 343-350$.

DORE, J., Holophrases, speech acts, and language universals. Journal of Child Ianguage, 1975, 2, 21-40.

DUNN, L.M., and SMITH, F.O. (Eds.) Peabody language development kit. (Level łl) Circle Pines, Ninn.: American Guiāance Service, 1965.

DUNN, L.M., and SMITi, F.O. (Eds.) Peabody language development kit. (Level \#2) Circle Pines, Minn.: American Guidance Service, 1966.

DUNN, L.M., HORTON, K.B., and SMITH, F.O., Peajody language development kit. (Level \#P) Circle Pines, Minn.: American Guidance Service, 1968.

DUNN, L.M., Peabody Picture Vocabulary Test. Minn.: Anerican Guidance Service, 1981.

ERVIN-TRIPP, S., Language development. In L.W. Hoffman and M.L. Hoffman (Eds.), Review of Child Development Research. New York: Russell Sage Foundation, 1966.

ERVIN-TRIPP, S., wait for me roller skate. In S. Ervin-Tripp and C. Mitchell-kernan (Eds.), Child Discourse.

New York: Academic Press, 1977.

EVANS, R.I., Jean Piaget: The Man And His Ideas. New York: E.P. Dutton and Company, 1973.

FISHBEIN, H.D., and OSBORNE, M., The effects of feedback variations on referential communication of chilaren. Merrill-Palmer Quarterly, 1971, 17, 243-250.

FORD, W., and OLSON, D., The elaboration of the noun phrase in children's description of objects. Journal of Experimental Child Psycholog:, 1975, 19, 371-382.

GALLAGHER, T.M., Revision behaviors in the speech of normal children developing language. Journal of Speech and Hearing Research, 1977, 20, 303-318. 
GARVEY, C., Requests and responses in children's speech. Journal of Cinild Language, 1975, 2, 4l-63.

GLUCKSBERG, S., KRAUSS, R.M., and WEISBERG, R., Referential communication in nursery school children: Method and some preliminary findings. Journal of Experimental Child Psychology, $1966,3,3 \overline{33-342 .}$

GLUCKSBERG, S., and KRAUSS, R.M., what do people say after they have learned how to talk? Studies of the development of referential comnunication. Nerrill-Palmer Quarterly, 1967, 13, 309-316.

GLUCKSBERG, S., KRAUSS, R.M., and HIGGINS, E.T., The development of referential communication skills. In F.D. Horowitz (Ed.), Review of Child Development Research Vol. 4, Chicago: University of Chicago Press, 1975.

GREENFIELD, P., and SMITH, J., The Structure of Comnunication in Early Language Develooment. New York: Academic Press, 1976.

FALLIDAY, M.A.K., Explorations In The Functions of Language. London: Edward Arnold, 1973.

FALLIDAY, M.A.K., Learning How To Mean: Explorations in the Development of Language. London: Edward Arnold, 1975.

HALLIDAY, M.A.K., Language As A Social Semiotic. Baltimore: University Park Press, 1976.

HOPPER, R., and NAREMORE, R.J., Chilären's Speech. New York: Harper and Row Publishers, 1978.

HYMES, D., Competence and performance in linguistic theory. In R. Huxley and $\bar{E}$. Ingram (Eds.), Language Acquisition: Models and Methods, New York: Academic Press, 1971.

JACOBSON, R., Linguistics and poetics. In T.A. Sebeck (Ed.), Style In Language, Cambridge, Mass.: MIT Press, 1960.

KRAUSS, R.M., ans GLUCKSBERG, S., The development of communication: competence as a function of age. Child Development, 1969, 40, 255-266.

MCCARTHY, D., Language development in children. In L. Carmichael (Ed.), Manual of Child Psychology. New York: Wiley, 1954. 
MILLER, L., Pragmatics and early childhood language disorders: communicative interactions in a half-hour sample: Journal of Speech and Hearing Disorders, 1978, $43,419-436$.

PETERSON, C.L., DANNER, F.W. and FLAVELL, J.H., Developmental changes in children's response to three indications of failure. Child Development, 1972, 43, 1463-1468.

PIAGET, J., The Language and Thought of the Cinild. New York: Harcourt, Brace and Co., 1926.

PRUTTING, C.A., Process 'prä/,ses/n: The action of moving forward progressively from one point to another on the way to completion. Journal of Speech and Hearing Disorders, $1979,44,3-\overline{30}$.

ROSENBERG, S., and COHEN, B.D., Referential processes of speakers anả listeners. Psychology Review, 1966, 73, 208-231.

RUEBUSH, B.K., Interfering and facilitating effects of test anxiety. Journal of Abnormal and Social Psychology, $1960,60(2), 205-212$.

SARASON,.S.B., DAVIDSON, K.S., LIGHTHALL, F.F., and WAITE, R.R., Rorschach behavior and performance of high and low anxious children. Child Development, 1958, 29, $277-285$.

SCHUELL, H., Differences Which Matter: A Study of Boys and Girls. Texas: Delta Kappa Gama Society, National office, 1947.

SEARLE, J.R. Speech Acts: An Essay in the Philosophy of Language. Cambridge: Cambridge University Press, 1969.

TOUGi, J., The Development of Meaning: A Study of Children's Use of Language. New York: Wiley, 1977.

WARDHAUGH, R., The Contexts of Language. Rowley, Mass.: Newbury House Publications, 1976.

Webster's Seventh New Collegiate Dictionary. Springfield, Mass.: G and C Merriam Company, 196I.

WiITEHURST, G., The development of communication: changes with age and modeling. Child Development, 1976, 47, $473-482$.

WOOD, B.S., Children and Communication. Englewood Cliffs: Prentice Hall, 1981. 
APPENDIX A

PERMISSION REQUEST LETTER

Dear Parents or Guardian,

I am a Portland State University graduate student doing a research project in speech and Hearing Sciences. The purpose of my study is to obtain information on children's descriptive communication. Descriptive communication refers to the ablility to represent an object, event, or relationship in words. It involves constructing a message that enables someone else to know to which the message refers. Because descriptive communication is often used academically, in subjects such as language arts, science and math, it is important that we learn more about children's descriptive abilities. This information will not only allow us to help children improve their descriptive skilis, but also will give us a basis for finding and helping those children who need special attention in this area.

I am requesting your permission for your child's participation in my study. The investigation involves presenting picture cards and eliciting cescriptions of them. The children participating in this study will be shown pictures and asked to describe them to a listener. The listener will try to guess the correct picture on the basis of the child's description. The total time needed for each child is 
approximately thirty minutes; fifteen minutes on two different days. Should your child participate in this study, they will also be given a hearing screening test as well as a test designed to determine their receptive vocabulary level. In no way will your child's name or the name of his/her school be used in reporting the results of this study.

Please sign below indicating your approval and return this letter with your child to school tomorrow.

Thank you for your help.

Sincerely,

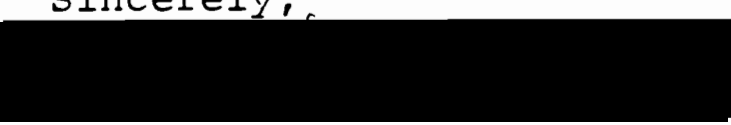

Eve Liejuran

Graduate Student, Speech and Hearing Sciences Portland State University

I herejy permit

Signature Name of Child to participate in Eve Liebman's language study.

Relationship to child Date 


\section{APPENDIX B}

\section{PICTURES USED IN THE STUDY}

Peabody Language Developmental Kits (Dunn and Smith Level \#l, 1965; Dunn and Smith Level \#2, 1966; Dunn et al. Level P, 1968)

Key: $\quad *$ = picture children described

- = picture listener pointed to after the first elicitation

I. Fruits and Vegetables

1. *cherries - level \#1 (E-3)

2. ${ }^{\circ}$ strawberries - level \#I (E-12)

3. oranges - level \#I (E-8)

4. banana - level \#l (E-2)

1. carrots - level \#P $(F-40)$

2. pumpkin - level \#P $(F-48)$

3. *apple - level \#l (E-I)

4. 'tomato - level $\# 1(E-13)$

II. Animals

1. cat - level \#I (B-2)

2. giraffe - level it 1 (B-47)

3. *dog - level \# $1(B-3)$

4. ${ }^{\circ}$ kangaroo - level it $(B-50)$

1. horse - level \#I (B-16)

2. lion - level \#I $(B-30)$

3. *deer - level $\#$ I $(B-30)$

4. ${ }^{\circ}$ cow - level \#1 (B-10)

III. Shoes

1. black boots - level \#l (C-25)

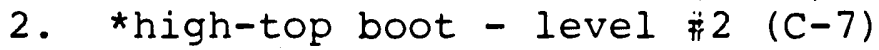

3. Odress shoe - level \#l (C-7)

4. clown's shoe - level \#2 (C-1)

1. *white leather shoes - level \#I (C-54)

2. Otennis shoe - level \#2 (C-15)

3. roller skate - level \#2 (C-10)

4. black, girl's shoe - level \#l (C-45) 
IV. Transportation

1. helicopter - level \#l (V-12)

2. train - level \#P $(T-33)$

3. *bicycle - level \#P ( $T-4)$

4. 'motorcycle - level \#l (V-27)

1. boat - level \#I (V-3)

2. airplane - level \#P $(\mathrm{V}-6)$

3. *station wagon - level \#I (V-II)

4. 'garbage truck - level \#I (V-18)

v. Kitchen Items

1. *pan - level $\$ 1(H-46)$

2. Opot - level \#l $(\mathrm{H}-47)$

3. iron - level \#l (is-9)

4. tea kettle - level it ( $\mathrm{H}-50)$

1. *spoon - level \#l ( $\mathrm{H}-49)$

2. ¿knife - level \#l (ii-44)

3. cup and saucer - level \#l ( $\mathrm{H}-39)$

4. glass - level \# $1(\mathrm{H}-43)$ 


\section{APPENDIX C}

\section{INSTRUCTIONS TO CHILDREN PARTICIPATING IN THE STUDY}

We are going to play a game in which you will have a chance to win a prize. Laurie (the listener) will close her eyes and I am going to point to one of these four pictures. I want you to tell her about the picture I point to without naming it. For example, if I point to this one (an owl) you could say it has feathers, is brown, flies, has big eyes, and comes out at night, but you can't say that it is an owl. Laurie will then open her eyes and try to guess, from what you tell her, which picture you're talking about. Each time she guesses the right picture from what you say, you'll receive one of these tokens. If you get ten of them, you will win the prize. (The prize was placed where the child could easily see it.) Now remember, you want to tell Laurie about the picture; what it looks like, what it is used for, and maybe what kind of noises it makes, but without naming it. You only get two chances to get her to guess the right picture. 

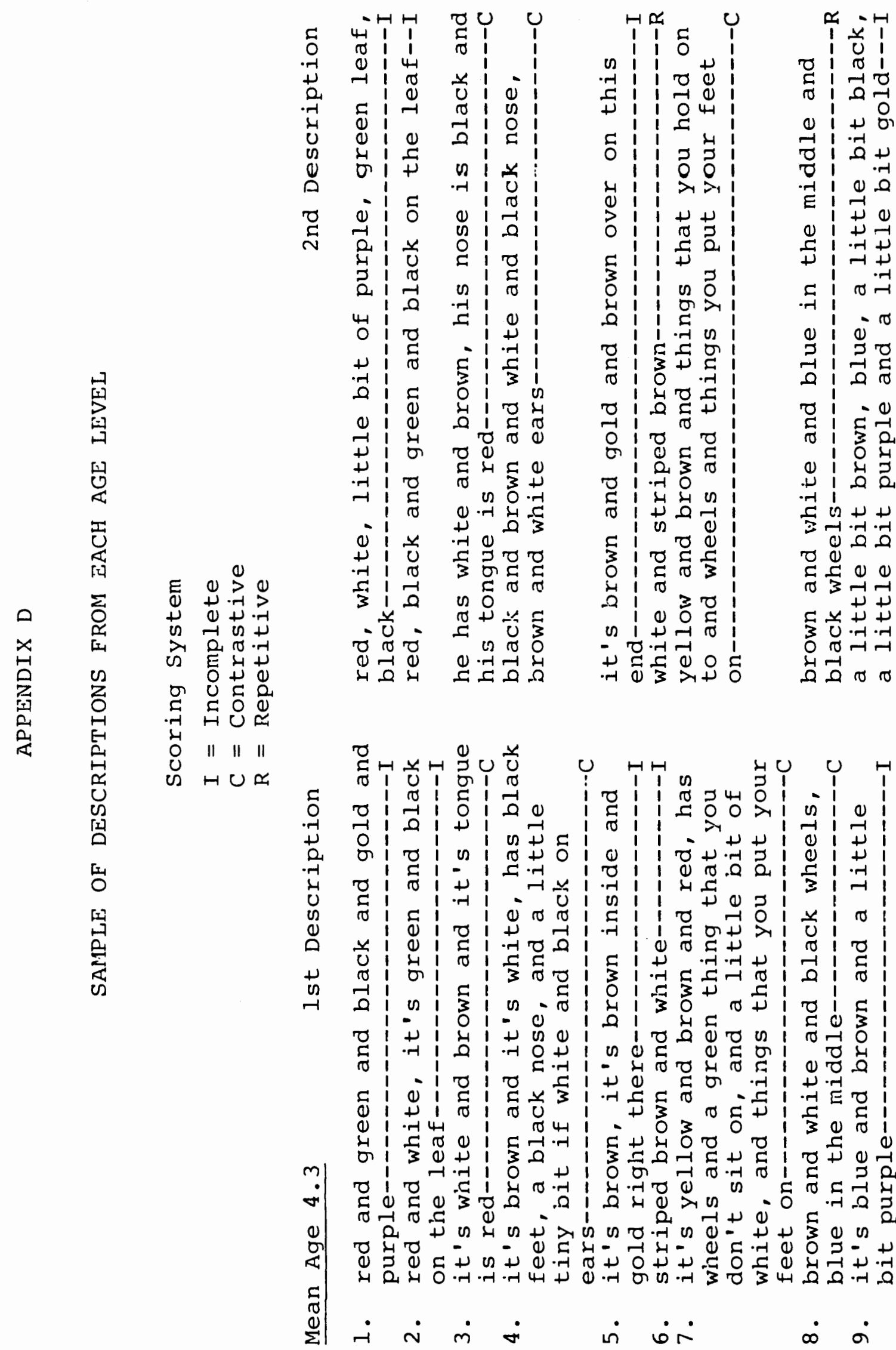


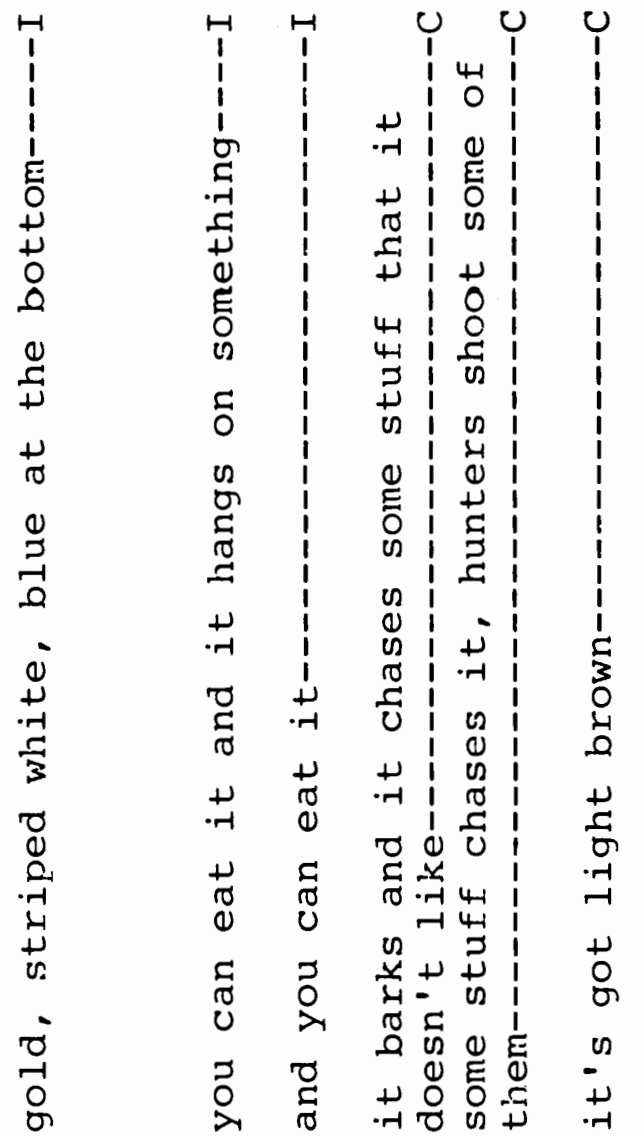
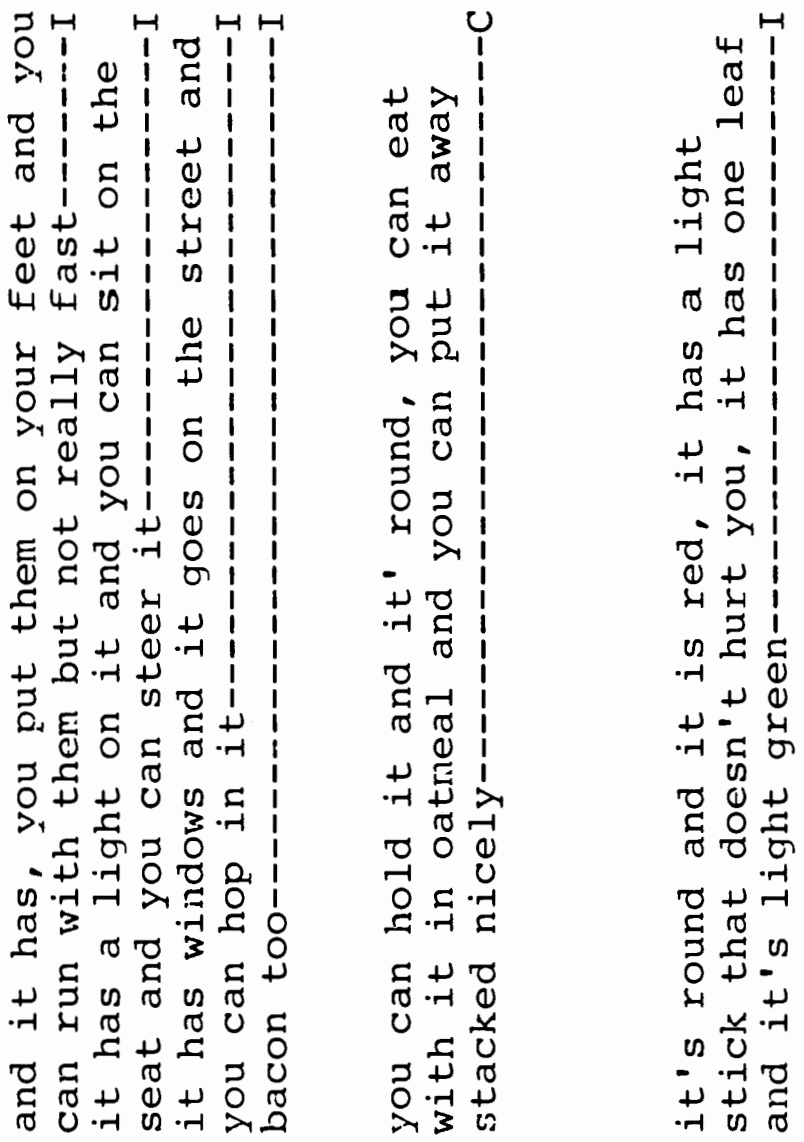

44 is

거디

วิન

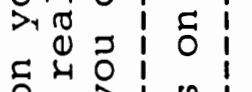

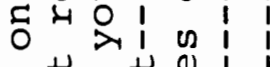

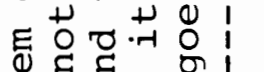

प्रे

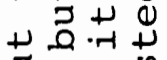

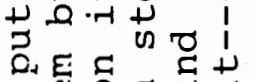

व

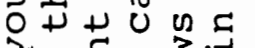

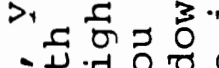

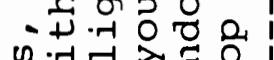

更

+

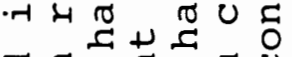

ช

สี

$\rightarrow \underset{0}{\pi}$

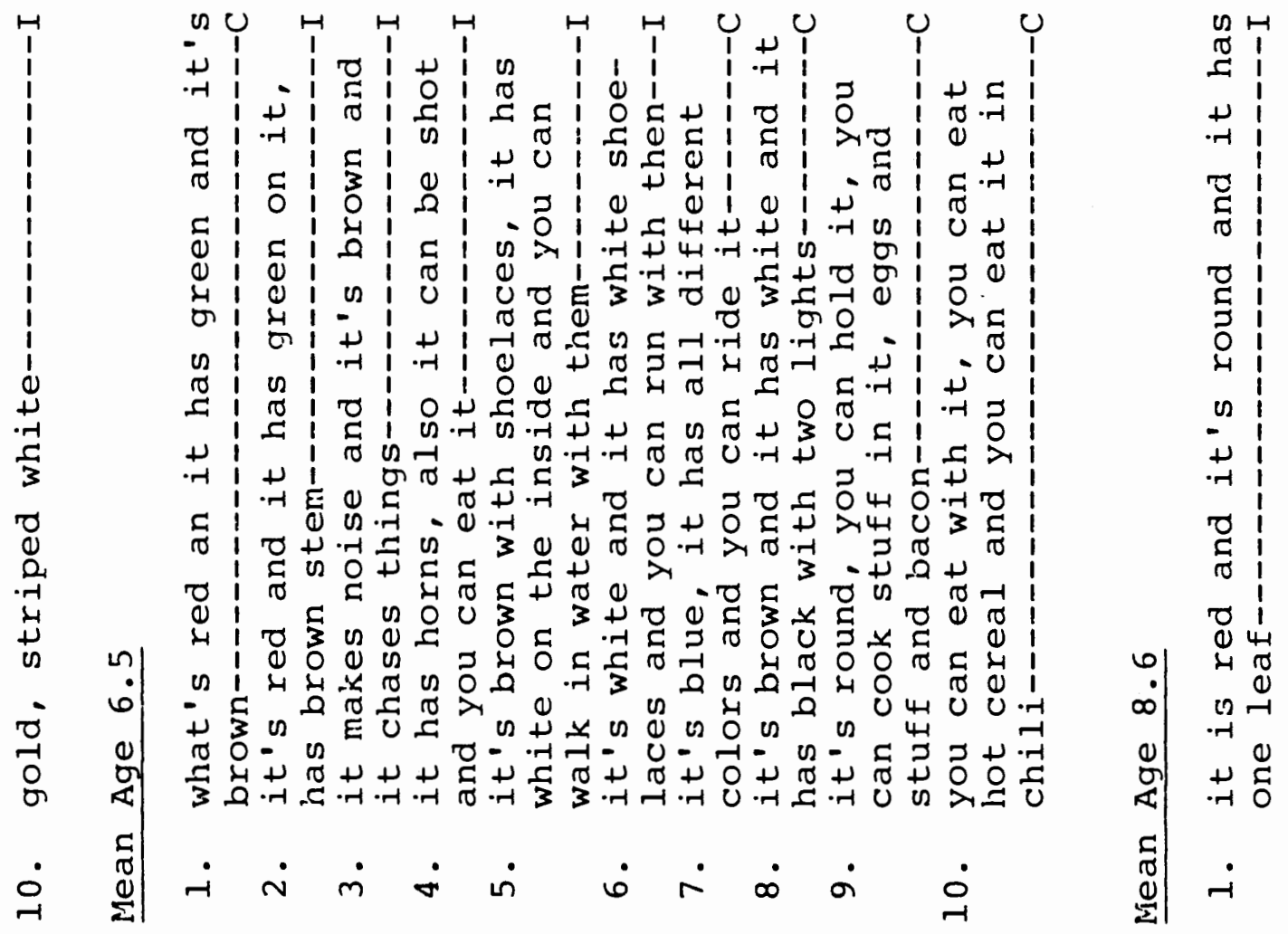




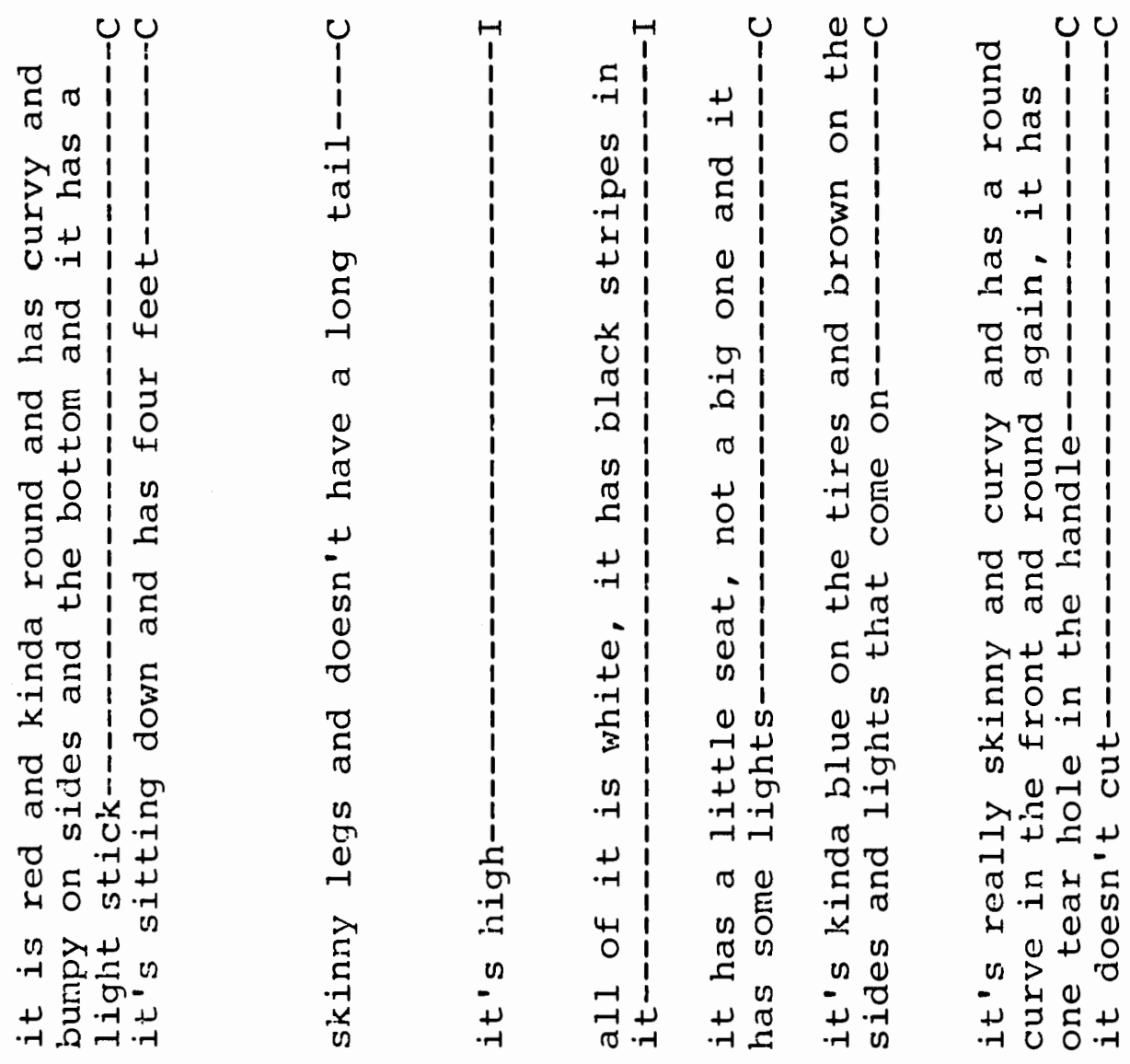

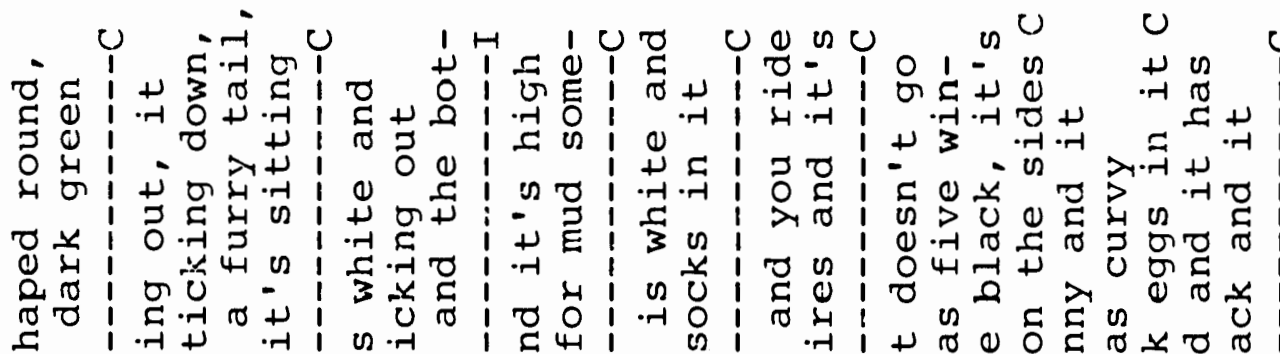
ब

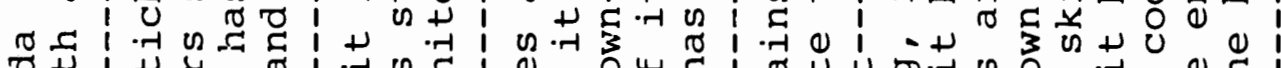

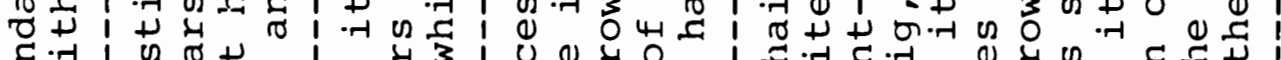

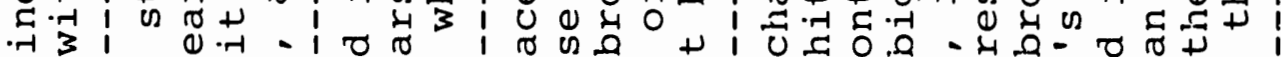

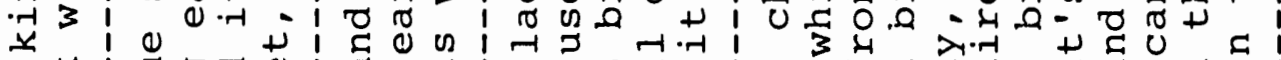

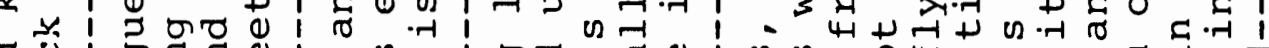
రు $\sigma^{2}$ (

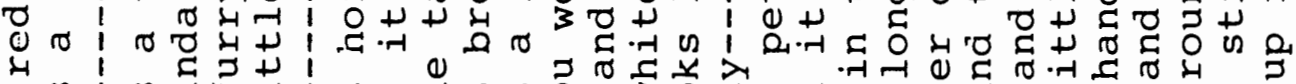

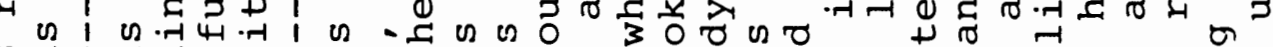

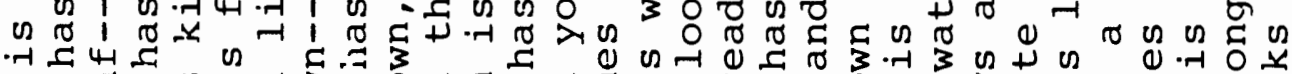

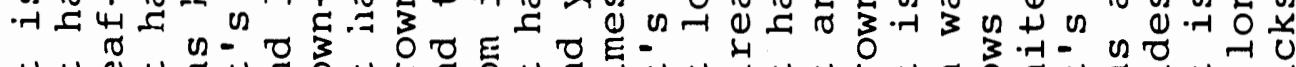

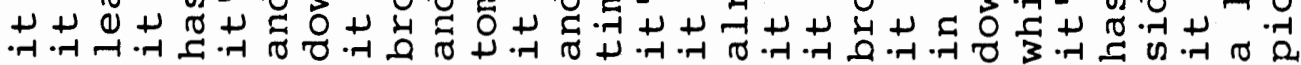
$\dot{\sim} \dot{m} \quad \dot{\nabla} \quad \dot{n} \quad \dot{0} \quad \dot{r} \quad \infty \quad \dot{\sigma} \quad \dot{0}$ 


\section{APPENDIX E}

\section{INSTRUCTIONS FOR JUDGES}

During a pilot run for my study, children were asked to describe one of four pictures from different categories to a listener. The children's descriptions are listed below. I will be showing you the four pictures the children saw in each category, and will point out the picture the children were asked to describe. After studying the pictures and description, I would like you to score the description as one of the following types of communication: Incomplete Communication: responses which contain less than what is necessary in order to distinguish a referent from nonreferents. (or) contrastive Communication: responses which contain what is necessary to distinguish a referent from nonreferents.

SAMPLE DESCRIPTIONS (We will discuss reasons for the scores given following each example.) NOTz: refers to picture child described.

Kitchen Items: pot, *pan, tea kettle, iron

1. real short handle; can pour hot soup out of it

2. dark blue; can hang it on the wall

3. can fry thing in it; has a handle, metal

4. has things on each side

5. has a flat bottom

6. blue; has a handle

INTER-SCORER RELIABILITY DESCRIPTIONS

Fruits: *cherries, strawberries, oranges, banana

1. red

2. one leaf 
3. has a branch and round things on it

4. eat it; long stem

5. One green leaf; red; four of them

6. red; pits

7. red; green leaf; stem

8. it's red, has a green leaf and a brown branch

Transportation: helicopter, train, *bike, motorcycle

1. light blue and yellow

2. ride it; two big wheels

3. has a seat and wheels; can hold on to it

4. has screws on it; can pump vineels up

5. kickstand, ten speed, seat

6. has hadnle bars

7. kinda yellow and brown; silver knob and white handles

8. has a seat, peddles and little knobs around it

Transportation: airplane, *car, garbage truck, boat

1. white

2. four wheels

3. can ride in it; has light; top on it

4. can go on trips with it; has windows; has a burnper

5. four wheels, brown on side windows

6. lights on the front; numbers on the front

7. wheels and doors have brown and yellow on it

8. has blue on front and on winaows

Kitchen Items: *spoon, knife, cup anả saucer, glass

1. dark blue; long stem at top to hold on to

2. round oval shape at bottorn

3. can eat with it; has handle

4. shiny; can put food in it

5. round on top

6. food goes in it

7. blue with white stripe and black

8. white stripe and blue strip

Fruits and Vegetailes: squash, carrots, tomato, *apple

1. round shaped; a little stem

2. one leaf

3. leaf an stem on it; lumpy; round

4. bite into it; red

5. red with stem coming up

6. yelloe dots on it

7. red and green; round

8. has black on it; yellow dots on it; a white spot

Thanks for you help!!!!! 


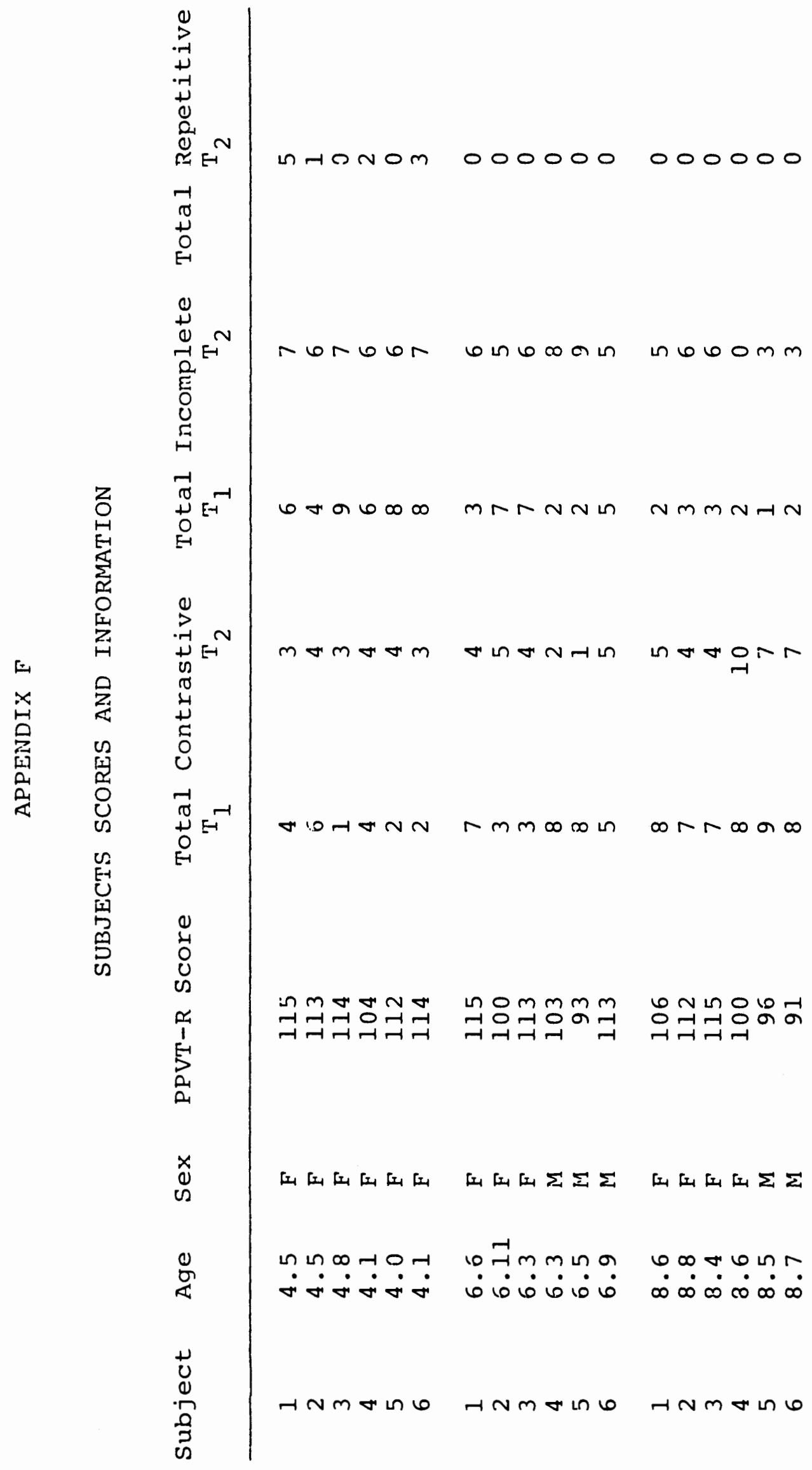

